\title{
V2-Specific Antibodies in HIV-1 Vaccine Research and Natural Infection: Controllers or Surrogate Markers
}

\author{
Ralf Duerr * and Miroslaw K. Gorny \\ Department of Pathology, New York University School of Medicine, New York, NY 10016, USA \\ * Correspondence: ralf.duerr@nyulangone.org; Tel.: +1-212-263-4159
}

Received: 1 July 2019; Accepted: 27 July 2019; Published: 6 August 2019

\begin{abstract}
Most human immunodeficiency virus (HIV) vaccine trials have lacked efficacy and empirical vaccine lead targets are scarce. Thus far, the only independent correlate of reduced risk of HIV-1 acquisition in humans is elevated levels of V2-specific antibodies identified in the modestly protective RV144 vaccine trial. Ten years after RV144, human and non-human primate vaccine studies have reassessed the potential contribution of V2-specific antibodies to vaccine efficacy. In addition, studies of natural HIV-1 infection in humans have provided insight into the development of V1V2-directed antibody responses and their impact on clinical parameters and disease progression. Functionally diverse anti-V2 monoclonal antibodies were isolated and their structurally distinct $\mathrm{V} 2$ epitope regions characterized. After RV144, a plethora of research studies were performed using different model systems, immunogens, protocols, and challenge viruses. These diverse studies failed to provide a clear picture regarding the contribution of V2 antibodies to vaccine efficacy. Here, we summarize the biological functions and clinical findings associated with V2-specific antibodies and discuss their impact on HIV vaccine research.
\end{abstract}

Keywords: HIV-1; V2 antibodies; vaccine design; natural infection; non-human primates; correlates of protection; correlates of disease progression; immunogenicity; functional immune response

\section{Introduction}

The almost 2 million human immunodeficiency virus (HIV) infections per year worldwide are an incentive to drive progress in the development of a preventive HIV vaccine [1]. The lack of vaccine efficacy in most antibody (Ab)- or T-cell-based vaccine trials and the extreme flexibility and diversity of the HIV envelope protein (Env), the only viral protein facing the immune system before an HIV infection takes place, has made targeted HIV vaccine design a challenging task. Thus far, the RV144 human vaccine trial in Thailand was the only study to report a modest vaccine efficacy in a modified intention-to-treat analysis [2,3]. Despite all the skepticism and controversies about RV144 and the correlates of reduced risk of infection [4-6], the proposed lead target, i.e., the hypervariable V1V2 region [2,7], gave direction to the field and provided hope that an Ab-based vaccine is feasible [8,9]. Post RV144, the HIV vaccine field faced a series of unresolved questions that needed to be addressed:

- Can vaccine efficacy and immune correlates be reproduced in other human and non-human primate (NHP) vaccine trials?

- How much did the results depend on the study population, infecting subtypes, and immunogens?

- Were the correlates of reduced risk of infection, and particularly the high levels of V2-specific antibodies (Abs) as the only independent variable, causally linked with protection or were they solely markers for unrelated protective responses?

- How do V2 Abs cooperate with other Abs, other adaptive, and innate immune responses? 
Aside from the few human vaccine efficacy trials [9], the majority of HIV vaccine research has been done using NHPs as the best available animal model of HIV/AIDS [10-13]. NHPs exhibit a high genetic and immunologic homology with humans; e.g., the human and rhesus macaque genomes are $\sim 91 \%$ identical (93.5\% in the alignable sequence without small indels), and humans and chimpanzees even share $\sim 98.5 \%$ of their genomes [14]. Nevertheless, slight differences between humans and NHPs have to be considered when interpreting NHP studies, specifically regarding Ab repertoires and functions [15-18], as well as challenge viruses, i.e., simian immunodeficiency virus (SIV) versus the humanized version simian-human immunodeficiency virus (SHIV), or HIV.

In addition, studies of natural infection have enabled the investigation of $\mathrm{V} 2$ responses that are derived "naturally" after infection with replication-competent primary viruses in the human system. These studies have helped to identify similarities between V2 Ab responses in natural infection and after vaccination. Also, they have enabled to distinguish the requirements for V2 high and V2 low immune responses, to recapitulate the development of functionally potent $\mathrm{V} 2 \mathrm{Abs}$, to isolate key monoclonal Abs (mAbs), and to identify how $\mathrm{V} 2 \mathrm{Ab}$ responses correlate with other immune responses and clinical outcome [19-22].

Structure/function studies have illuminated structural requirements in defined V2 epitope regions for the binding of at least four different V2 Ab classes [23-28]. Env accessibility, inducibility upon immunization or natural infection, and associated antiviral functions are crucial features when assessing biological functions of V2 Abs. The isolation and characterization of V2 mAbs have been critical to demarcate key attributes for different V2 Abs [21,22,29-37]. Besides "vaccine-inducible" V2 Abs that are usually non-neutralizing or only weakly neutralize tier 1 viruses, broadly-neutralizing Abs (bnAbs) have been characterized that target glycan-dependent quaternary epitopes in (V1) V2. It has not been possible to induce glycan V2 bnAbs by active vaccination, though germline-targeting immunogen design and successive boosting strategies are currently under investigation to stimulate a directed ontogenetic development of bnAbs $[38,39]$. Passive vaccination approaches with glycan V2 bnAbs have the promise of complementing combinational treatment protocols [40]. Here, we provide a comprehensive literature review on the biological features of V2-specific Abs. We discuss their potential contribution to vaccine efficacy versus the possibility that vaccine-inducible V2 Abs merely serve as surrogate markers for other immune responses.

\section{The Multifaceted V1V2 Region and Its Epitope-Specific Abs}

The variable V1V2 region is located at the apex of the HIV-1 Env trimer and contributes to trimer stability, cellular attachment, and viral entry, e.g., via interaction with $\alpha 4 \beta 7$ and the CCR 5 or CXCR4 co-receptors [24,41]. V1V2 harbors multiple N-glycosylation sites and shields V3 and co-receptor binding sites in the native, closed Env conformation. V1V2 exhibits high structural plasticity and flexibility [42,43] and can transition between different structural states (Section 2.1). There is excessive sequence variation between different viruses and clades (Figure 1). Even within clades, the V1V2 sequence is highly variable, but is interfused with structurally conserved sub-domains, specifically in V2, and these are the main targets for Abs (Figure 2). Plasma V1 Abs are sequence-specific and can be detected almost exclusively against autologous antigens of the infecting virus. In contrast, at least four classes of anti-V2 Abs have been described. They are cross-reactive and detectable in human or NHP plasma samples with heterologous V1V2-fusion proteins and/or V2 peptides [22,35,44,45]. To assess the role of V1V2 and V2-specific Abs in vaccine research, knowledge on the structural V1V2 architecture is essential since the accessibility of the V1V2 epitopes within the native versus open trimer forms affects the antiviral functions of the respective V2 Abs.

\subsection{Conformational Plasticity of V1V2 and Structural Requirements for the Binding of Different V2 Ab Classes}

V1V2 forms a five-stranded $\beta$-barrel structure at the apex of the native closed HIV Env trimer (Figure 3) [46,47]. Upon CD4 activation, the trimer opens, and V1V2 undergoes rotational movements away from the three-fold trimer axis [48]. When the trimer (and V1V2) are released from the constrained 
closed conformation in native Env, in which V1V2 is mostly found in the $\beta$-barrel conformation, V1V2 transitions into a preferential $\alpha$-helical conformation within the open trimer [22]. The different conformational states can be probed with four kinds of V2 Ab classes (Figures 2 and 3) [49].

$\mathrm{V} 2 \mathrm{i}$ Abs (such as 830A) bind a conformational epitope overlapping the integrin binding site and preferentially detect the $\beta$-barrel conformation. In contrast, V2p Abs (such as CH58) bind linear V2 peptides corresponding to the C-strand of V1V2 (centered on aa 170-176) and are specific for the $\alpha$-helix (or helix-coil/coil-helix) conformation. The glycan-dependent, quaternary V2q Abs (such as PG9) preferentially detect the closed native Env conformation with V1V2 in $\beta$-barrel conformation, whereof the trimer-dependent Ab subclass V2qt (such as PGT145) is exclusive for closed native trimers (Figure 3) [22,49]. V2q and V2qt Abs are both broadly neutralizing. V2-specific Abs that were suggested as correlates of protection in RV144 belong to the V2i and V2p Ab classes, which are weakly- or non-neutralizing (Section 2.3) [2,50,51].
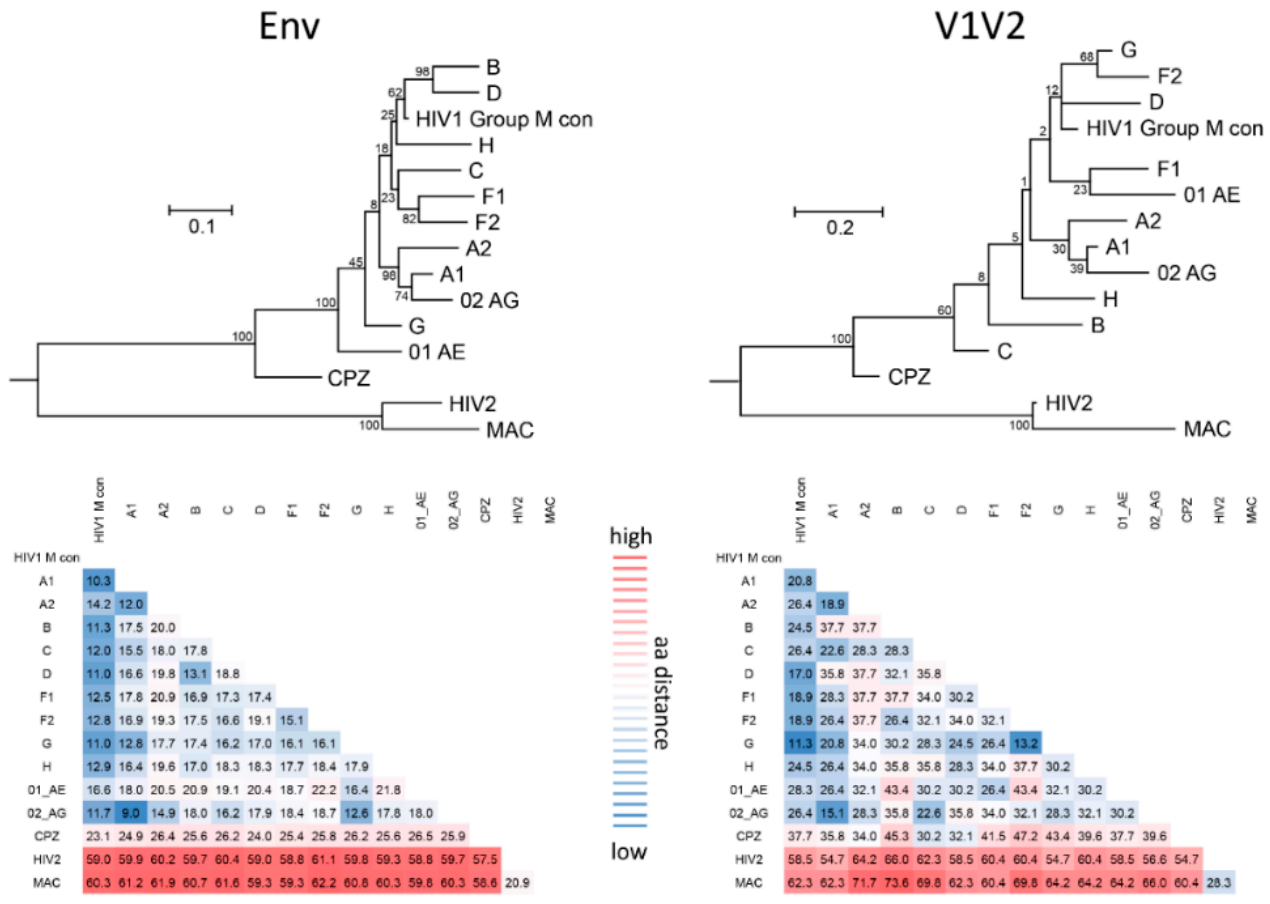

Figure 1. Phylogenetic diversity and aa distance analysis of diverse HIV-1 clades, HIV-2 and SIV. (Top): maximum likelihood phylogenetic trees of Env (left) and V1V2 (right) aa consensus sequences of major HIV-1 clades, HIV-2, and SIV from chimpanzees (cpz) and macaques (mac). An additional consensus sequence summarizing all HIV-1 group $M$ consensus sequences was used (HIV-1 group $\mathrm{M}$ con). The consensus sequences were downloaded from the Los Alamos National Library (LANL) Database, if available, or generated from the alignments of functional aa sequences that were used for Figure 2 (Consensus Maker, LANL Database). Maximum likelihood phylogenetic trees were constructed using MEGA v5.2, and the Poisson substitution model with 200 Bootstrap replicates; Bootstrap values are indicated. (Bottom): pairwise aa distance analysis between Env (left) and V1V2 (right) consensus sequences. The heatmap displays aa distances in percent, color-coded according to the scheme in the middle. The distances were calculated in MEGA v5.2 using the Neighbor-joining p-distance model.

\subsection{High Sequence Diversity in V1V2 and Clade-Specific Differences in Antigenicity and Immunogenicity}

One of the major challenges towards the development of an effective HIV vaccine is the enormous viral sequence diversity $[55,56]$. HIV-1 group $\mathrm{M}$ clades reach $>20 \%$ aa distance in Env, which reaches even $>35 \%$ in V1V2 (Figure 1). Considering the importance of rhesus macaques as a model system and SIV as frequently applied challenge viruses, it is important to know that SIVmac and HIV-1 group $\mathrm{M}$ clades differ up to $>60 \%$ in Env and $>70 \%$ in V1V2. A closer look into the V1V2 epitope regions 
reveals that anchor glycans such as N160 and N156, the lysine-rich region around K169, and the integrin binding site (179-181) are generally present in most viruses/clades, suggesting a conserved biological and possibly antiviral role of V2 Abs. However, the aa frequency distribution at key residues such as aa 169 and aa 181 is highly variable and largely differs by virus/clade (Figure 2). In RV144, viruses matching the vaccine at K169 and having a mismatch at I181 had an estimated vaccine efficacy of $48 \%$ and $78 \%$, respectively [7]. K169 has also been linked with the development of strong $\mathrm{Ab}$ responses in natural infection and associated with antibody-dependent cellular cytotoxicity (ADCC) or bnAb activities $[20,21,44]$. Therefore, it is expected that correlates of reduced risk of HIV infection differ considerably when study populations and circulating clades vary. Additionally, the quaternary structure in Env and V1V2 varies considerably between clades. The structural comparison of SOSIP trimers of diverse clades revealed differences in glycan organization, processing, and conservation [57]. Also, the quaternary structural arrangement of the V1V2 regions in two clade C SOSIPs differed substantially to those of clades A and B [58]. As such, the currently ongoing human vaccine trial HPTN702 in South Africa with predominantly clade C infections may significantly differ in outcome from the RV144 trial in Thailand with mostly CRF01_AE infections [3].

Compared to other Env regions such as V3, V1V2 is far less immunogenic as evident by the weaker plasma binding levels of V2 Abs in human cohorts of HIV-1 infection and the absence of V2 $\mathrm{Ab}$ responses in a fraction of the participants [19,59-61]. The detection of $\mathrm{V} 2 \mathrm{p}$ Ab responses in HIV-1 infected individuals is less frequent than $\mathrm{Ab}$ responses to conformational V2i epitopes $[19,20,61,62]$. For example, in a Cameroonian cohort, $53-85 \%$ of plasma samples were positive against four V1V2 gp70-fusion proteins (preferably detected by V2i Abs), whereas $40-61 \%$ were reactive with four V2 peptides (preferably detected by V2p Abs). The screening of sera of HIV-1 infected individuals in clade $B$ cohorts in Europe and the USA yielded even lower V2p reactivities (12\% and 21\%, respectively) [61,62]. However, V2i and V2p directed immune responses could be readily induced in RV144, presumably supported by using the immunogenic A244 (CRF01_AE) gp120 construct [2,63,64]. Post RV144, diverse V1V2 antigens have been generated that can bind several V2 Ab classes and were able to elicit functional $\mathrm{V} 2 \mathrm{i}$ and $\mathrm{V} 2 \mathrm{p} \mathrm{Ab}$ immune responses upon immunizations in rabbits or rhesus macaques [49,65-68]. The profiling of linear peptide-binding responses after SIV versus HIV Env immunizations in macaques has shown that HIV-1 induced immune responses focus on V3 with the only exception being the vaccine strain A244, which focuses the response to V2. In contrast, SIVmac239 responses consistently focused on V2 [69]. Furthermore, V1 Ab responses were more frequent in SIV compared to HIV-1 immunizations. The presence of additional disulfide bonds in V1 and V2 of SIVmac is the likely cause for these observations (Figure 2) [70]. Differences in glycan content and composition (complex/high-mannose glycans) and the capacity of Env glycoproteins to stimulate the expression of genes involved in innate or adaptive immune responses in the context of different vectors and adjuvants may have contributed to the observed dissimilarities in immunogenicity between SIV and HIV-1 [38,69,71-76]. Of interest, removal of glycans in V1 of SIV gp120 can redirect the humoral immune responses to V3 [75]. Based on these facts, SIV challenge and immunization experiments have to be analyzed with necessary caution considering inherent sequence and immunogenic features of SIV.

\subsection{Antiviral Functions Differ According to V2 Ab Class and Epitope Region}

Different structural binding modalities of the V2 Ab classes are associated with particular biological and antiviral features.

\subsubsection{Neutralization}

Neutralization plays a primary role in vaccine-mediated protection against most viruses, and animal challenge experiments with passive administration of bnAbs indicate that bnAbs can confer protection against HIV if appropriate levels are reached $[9,77,78]$. However, it has not been possible to induce bnAbs upon vaccination, and the neutralizing Ab responses in RV144 and other human vaccine trials were largely restricted to tier 1 viruses that waned rapidly [79]. 


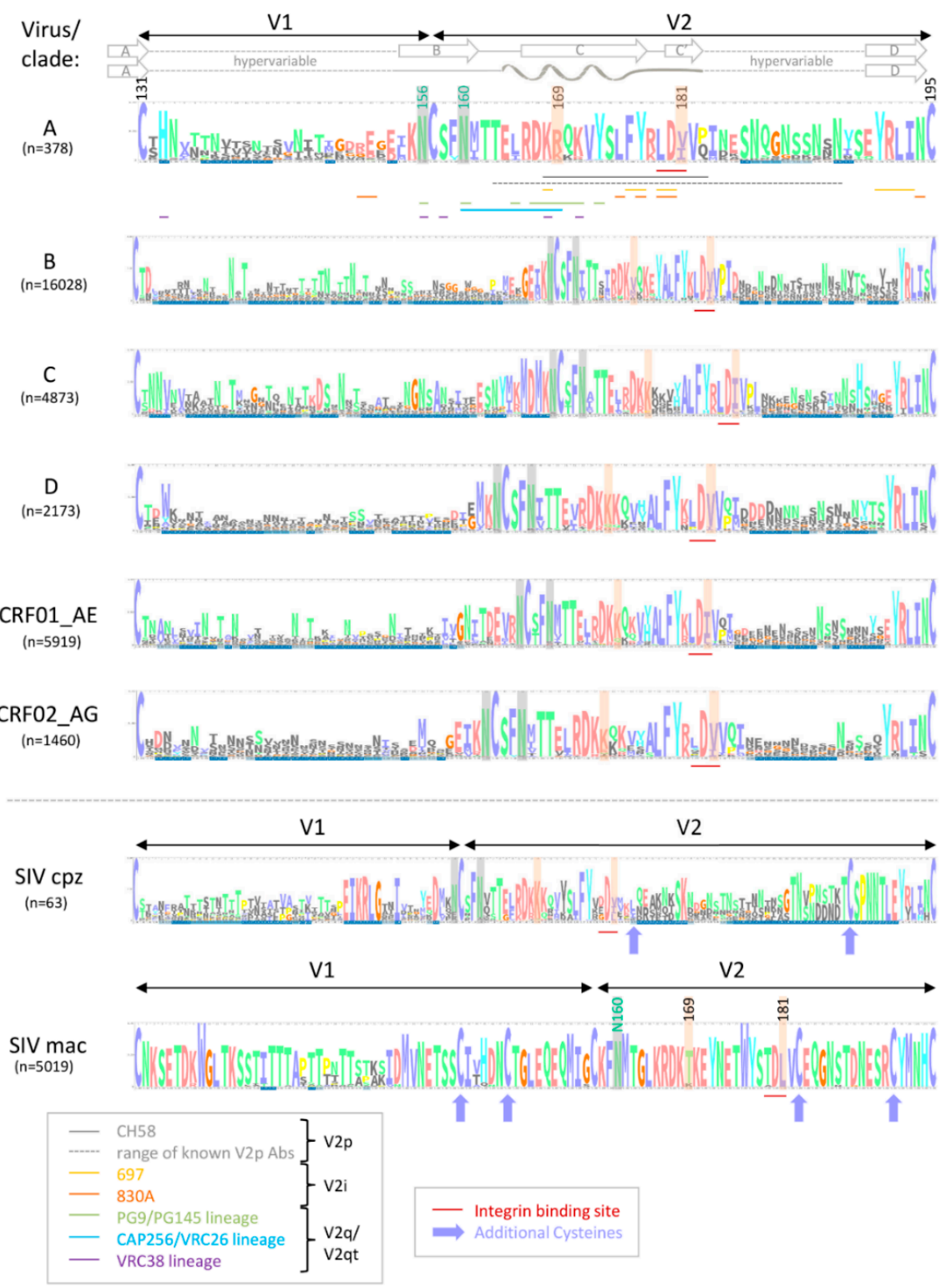

Figure 2. Comparative V1V2 sequence and epitope analysis across major HIV-1 group M clades and SIV. Sequence logo analyses are shown for the six most prevalent HIV-1 group M subtypes and circulating recombinant forms (CRF) in comparison to SIV from chimpanzees (cpz) and macaques (mac). Sequence logos were performed using the Skylign tool (skylign.org) with alignments using all functional aa sequences per virus/clade, downloaded from the LANL Sequence Database. The number of sequences used per logo is shown in parenthesis on the left (n). V1 and V2 loops, their hypervariable regions, and the $\beta$-barrel (top; native closed Env; $\beta$-strands labeled with A, B, C, $C^{\prime}$, and D) versus $\alpha$-helical conformation (bottom; open Env) are indicated by the schematic at top. The integrin binding site and $\mathrm{V} 1 \mathrm{~V} 2 \mathrm{Ab}$ epitopes are indicated with colored lines below the sequence logos according to the box on the lower left. The full set of epitopes is shown for HIV-1 subtype A representatively. Additional cysteines in SIV are highlighted with purple arrows. A dark blue field below the stack of aa indicates occupancy $<75 \%$ for the respective site. Sites with $<5 \%$ occupancy were removed from the sequence logos for better clarity. Functionally important aa positions are highlighted: asparagines of the potential N-glycosylation sites N156 and N160 are labeled in green and highlighted with a gray background; sites of immune pressure in RV144 [7], i.e., positions 169 and 181, are labeled and highlighted with an orange background. Epitope and structural regions are indicated according to reference papers and the LANL Immunology Database (Section 2) [22,46,47]. 
(a)
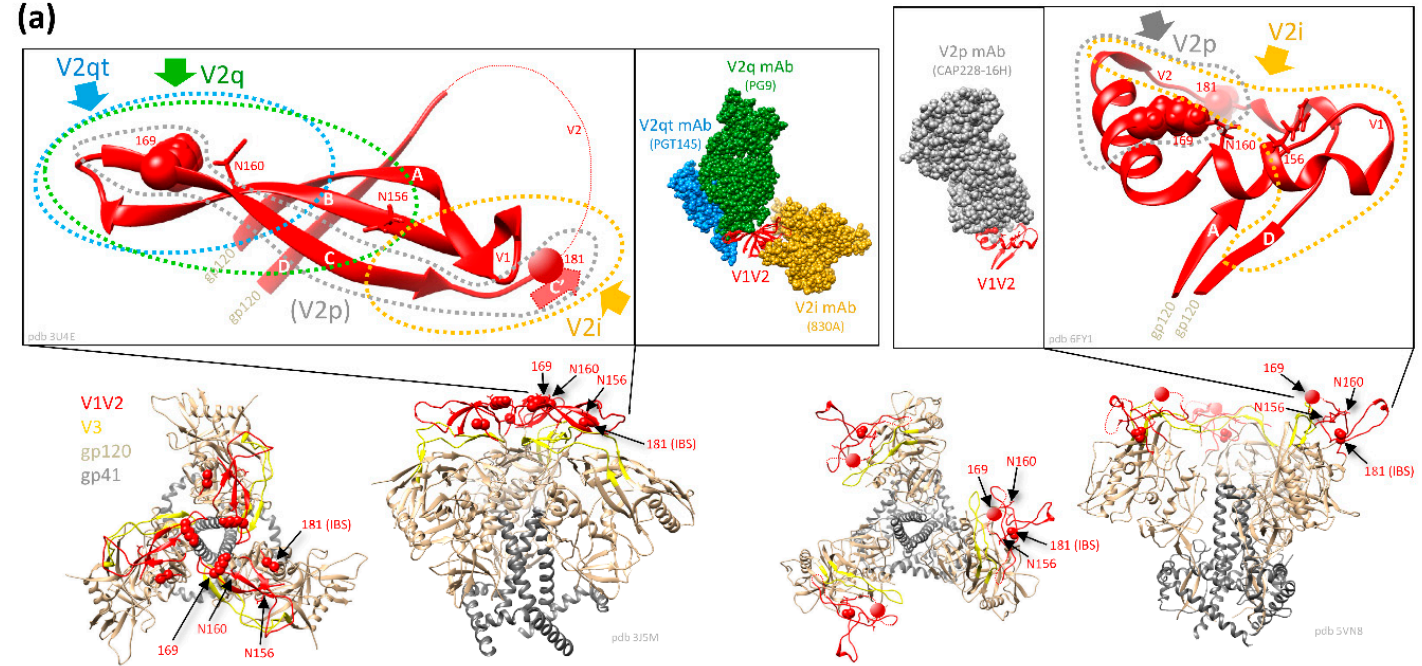

closed trimer-V1V2 $\beta$-barrel

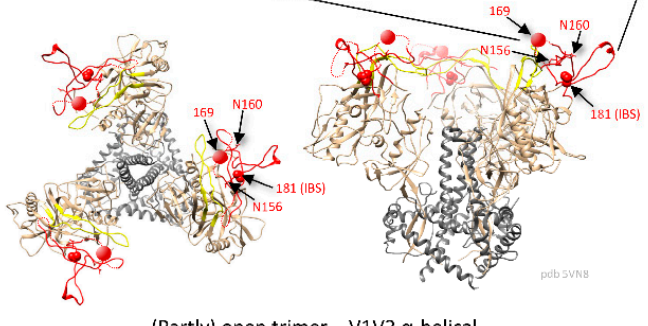

(b)

\begin{tabular}{|l|l|}
\hline \multicolumn{3}{|c|}{ V1V2 in native/closed Env } \\
\hline$\beta$-sheet & +++ \\
\hline$\alpha$-helix & - \\
\hline V2q & +++ \\
\hline V2qt & +++ \\
\hline V2i & $+(+)$ \\
\hline V2p & $(+)$ \\
\hline
\end{tabular}

\begin{tabular}{|l|l|}
\hline \multicolumn{1}{|c|}{ V1V2 in CD4i/open Env } \\
\hline$\beta$-sheet & $(+)$ \\
\hline$\alpha$-helix & $++(+)$ \\
\hline V2q & $(+)$ \\
\hline V2qt & - \\
\hline V2i & $+(+)$ \\
\hline V2p & +++ \\
\hline
\end{tabular}

Figure 3. Conformational plasticity of the variable V1V2 region and structural requirements for the binding of different V1V2-specific Abs. (a) Trimeric architecture of HIV-1 Env in a closed (pdb 3J5M, Env derived from a PGV04 Fab-stabilized SOSIP co-structure [46]) and an open conformation (pdb $5 \mathrm{VN} 8$, Env derived from a b12 Fab-stabilized SOSIP co-structure [52]). Env regions are colored as indicated in the legend; e.g., V1V2 regions are shown in red and V3 regions in yellow. Key V1V2 residues are labeled in one protomer: conserved N-glycosylation sites N156 and N160 are shown in stick representation and sites of immune pressure in RV144 as spheres, i.e., aa 169 and aa 181, the latter being part of the integrin binding site (IBS). Boxed: magnification of V1V2 regions with encircled antigenic V1V2 regions, shown for "closed Env" in preferential $\beta$-sheet conformation (left, pdb 3U4E, V1V2 derived from a PG9-stabilized co-structure [53]) and for "open Env" in preferential $\alpha$-helical conformation (right, pdb 6FY1, V1V2 derived from a CAP228-16H-stabilized co-structure [22]). V1 and $\mathrm{V} 2$ loops, gp120 stumps, and the $\beta$-sheets A-D are indicated. The binding pattern of different $\mathrm{V} 2 \mathrm{Ab}$ classes is schematically shown with colored ovals and arrows. mAb-bound V1V2 co-structures are displayed in additional boxes. For the V1V2 $\beta$-barrel conformation (left) an overlay was generated for PGT145 mAb-bound V1V2 (pdb 5V8L [54]), PG9 mAb-bound V1V2 (pdb 3U4E), and 830 mAb-bound V1V2 (pdb 4YWG [47]) using Matchmaker in Chimera v.1.13.1 (matching restricted to V1V2 regions). Schematics of key regions were manually added if structurally not resolved, i.e., $\beta$-strand $C^{\prime}$ (arrow), some V1 and V2 loops (red dashed lines), and some aa 169 and 181 residues (spheres). (b) Secondary structural content of V1V2 and preferential binding patterns of the different V2 Ab classes to the native/closed versus open Env conformations. Epitope accessibility/binding strength of respective Ab classes is scaled as follows: - absent, + weak, ++ strong, +++ very strong. Parentheses indicate variation within a class. V2 Ab epitopes: V2q: quaternary, V2qt: quaternary and trimer-dependent, V2i: conformational epitope including the IBS, V2p: linear (peptide) epitope. Quantification was done according to reference papers (Sections 2.1-2.3). SOSIP: soluble, stabilized HIV Env trimers with an additionally introduced disulfide bond ("SOS") and an isoleucine to proline mutation ("IP").

The majority of vaccine-induced Abs are $\mathrm{V} 2 \mathrm{i}$ mAbs that weakly neutralize mostly tier 1 pseudoviruses (Table 1) [31,34,35,65,80] with a neutralizing activity that is similar to other weakly-neutralizing mAbs directed against the CD4-binding site (CD4bs) and the V3 region [81]. In 
contrast, the few known human V2p Abs are mostly non-neutralizing with the exception of human CH58, CH59, and HGP68, which have modest activity against tier 1 viruses (Table 1) [31,80]. Based on their limited capacity to neutralize a few tier 1 viruses and none of the tier 2 viruses, V2i and V2p Abs are often classified as non-neutralizing Abs [82].

Table 1. Ab effector functions according to V1V2 Ab class.

\begin{tabular}{ccccc}
\hline V2 Ab Class/Effector Functions ${ }^{\mathbf{1}}$ & $\mathbf{\text { V2qt }}$ & $\mathbf{V 2 q}$ & $\mathbf{V 2 i}$ & $\mathbf{V 2} \mathbf{p}$ \\
\hline Neutralization & +++ & +++ & $+(+)$ & $(+)$ \\
viral capture & +++ & +++ & $+(+)$ & + \\
ADCC & + & + & + & + \\
ADCP & + & + & + & n.a. \\
$\alpha 4 \beta 7$ inhibition & - & - & $(+)$ & ++ \\
\hline
\end{tabular}

${ }^{1}$ Quantification of effector functions from - absent to + weak, ++ intermediate and +++ strong. Parentheses indicate variation within the Ab class. Quantification according to reference papers as described in Section 2.2; n.a.: no data available.

\subsubsection{V2 Broadly Neutralizing Antibodies}

BnAbs occur in a small percentage of HIV-1 infected individuals $(<10 \%)$ after $1-3$ years of continuous antigenic stimulation and maturation [83]. A large number of bnAbs have been characterized that mainly target six epitope regions of Env. Key regions are the membrane-proximal external region (MPER) of gp41, the CD4bs, the gp120/gp41 interface, the fusion peptide, the V3 glycan region, and the apical V2 glycan region [84-88]. Depending on the cohort, $10-40 \%$ of individuals with bnAb reactivities contain V2 bnAbs $[33,89]$. V2 bnAbs have been isolated from diverse donors and include PG9 and PG16 [32], PGT141-145 and PGDM1400-1412 [33,90], CH01-04 [91], CAP256-VRC26.01-33 [29,92], BG1 [45], and N90-VRC38.01-11 [93]. V2 bnAbs target a glycan-dependent, quaternary (V2q), and, for some $\mathrm{Ab}$ lineages also trimer-dependent (V2qt) epitope at the tip of the trimer (Figure 3). Common features of most V2q/qt bnAbs are their high potency (Table 1) and broad cross-reactivity, combined with a generally low degree of auto-reactivity. In contrast to several other bnAb classes, most V2 bnAbs bind trimeric Env monovalently with only one Ab per trimer at the apex close to the three-fold symmetry axis. They generally possess unusually long CDRH3 loops ( $\geq 24$ aa) that can penetrate the glycan shield to reach the lysine-rich binding motif in the C-strand of V2 with K169 as a common requirement. These bnAbs are dependent on glycans, specifically N160, for binding, neutralization, and potentially to drive their development [94,95]. V2 bnAbs have an increased propensity for incomplete neutralization $(<100 \%)$ and non-sigmoidal neutralization curves, which has been attributed to glycosylation heterogeneity [96,97]. Stabilization of the V2 loop and/or the closed Env trimer can enhance the presentation of V2 bnAb epitopes [68,98-100], yet a certain degree of breathing in the Env trimer is required for efficient binding of V2 bnAbs [54]. Current strategies aim to optimize their usage in passive vaccinations (e.g., Phase 1 clinical trial NCT01937455 for mAb PG9) [40,87] and to recapitulate their sophisticated maturation in vaccine settings using germline-targeting immunogens with guided sequential boosting [39].

\subsubsection{Fc-Mediated Effector Functions and Innate Immunity}

V2 mAbs can mediate phagocytosis, which correlated with protection in a rhesus macaque study [101], but their activity is moderate and comparable to V2i, V2q/qt, V3, and CD4bs mAbs (Table 1) [65,102-104]. ADCC, which is a correlate of immunity in one animal study [105] and a secondary correlate of immunity in the RV144 vaccine trial when corrected for low Env-specific plasma IgA levels [2], can be mediated by V2i, V2p and V2q/qt mAbs (Table 1) [21,31,65,106,107]. Epitope mapping of V2 Abs identified in RV144 indicated that the immune response was largely directed at a linear V2 epitope including K169 [51,108]. Isolation of such K169-directed V2p Abs, after RV144 and in natural human infection, indicated a common usage of the $\lambda$ light chain complementarity-determining 
region 2 (CDR2) motif, ED, for binding to K169 [31,109]. The role of V2p mAbs, and to a lesser extent V2i mAbs, in blocking the binding of V2/Env to $\alpha 4 \beta 7$ is discussed in Section 5.

While the antiviral functions of vaccine-inducible V2i and V2p Abs are mostly limited in strength, concerted actions of poly-functional immune responses might provide additive functions [110-113]. V2p Abs isolated from RV144 vaccinees have been shown to synergize with C1 Abs for neutralization, infectious virus capture, and ADCC, achieving ADCC activities at $\mathrm{CH} 58$ concentrations similar to the ones detected in the plasma of RV144 vaccinees [114]. The importance of innate immune responses seems to be more and more evident, and are supported by the facts that (i) vectors and adjuvants with improved capabilities to activate innate immune responses affect vaccine efficacy, (ii) macaque challenge experiments suggest innate immune responses as correlates of protection, and (iii) V1V2-specific complement activating serum immunoglobulin $\mathrm{G}(\mathrm{IgG})$ significantly, though weakly correlated with inverse infection risk in RV144 [110,115].

\section{Human Vaccine Efficacy Trials and the Role of V2 Abs}

\subsection{RV144 Reassessed in the Context of Other Human Vaccine Trials}

The six completed human HIV-1 efficacy (Phase III) and proof of concept (Phase IIb) vaccine trials indicated that the development of an Ab-based vaccine might be more likely than a T-cell-based vaccine (Table 2). Both T-cell-focused trials, i.e., STEP and Phambili, were stopped due to an increased risk of infection in vaccinated participants, particularly observed in the STEP trial $[116,117]$. Among the four other vaccine trials, which included the envelope region as immunogen/vaccine target, the vector prime/gp120 protein boost regimen in RV144 proved superior to the gp120 protein-based trials VAX003 and VAX004 and the DNA/vector-based trial HPTN 505 [3,118-120]. RV144 was the only study that achieved moderate vaccine efficacy of $31.2 \%$ after 3.5 years follow-up in a modified intention-to-treat analysis [3,5]. Elevated levels of V2 Abs against V1V2 fusion proteins or V2 peptides were identified as the only independent variable that correlated with reduced risk of infection and sieve analysis identified signatures of selection pressure in the V2 region of breakthrough viruses [2,7,50,51]. Low plasma IgA levels in combination with ADCC responses were suggested among other secondary parameters (Section 3.2) as possible effector mechanisms in conferring protection [2,31,51,121], yet a complete mechanistic explanation remains elusive. V2 Ab responses in HPTN 505 and VAX004 were low in magnitude and infrequent. In contrast, both VAX003 and RV144 had strong and frequent V2 $\mathrm{Ab}$ immune responses in the majority of vaccinees, which, surprisingly, were generally stronger in VAX003 compared with RV144 $[2,63,118]$. Detailed serological analyses revealed that more than four gp120 protein boosts in VAX003 drove functionally more anergic IgG2 and IgG4 responses, whereas, in RV144, IgG1 and IgG3 responses dominated and were associated with poly-functional humoral effector functions [122-125]. IgG3 responses were considered particularly critical based on the pinpointed efficacy of fractionated V2 IgG3 [125] and the efficient elicitation of IgG3-mediated Fc-effector functions and complement-activation in HIV and other viral infections $[123,126,127]$. Of interest, Ab immune responses waned over time in both studies. In VAX003, IgG responses peaked after boosts 3 and 4 and declined after boosts 5-7. In RV144, IgG responses peaked after the second and final protein boost. Subsequently, the V2 Ab response rate against cyclic V2 peptides declined from $97 \%$ at two weeks post-immunization to $19 \%$ at 28 weeks post last vaccination with a 10 -fold drop in binding titers $[63,122,124]$. It remains open whether this drop in response rate contributed causally to the decline in vaccine efficacy from $\sim 60 \%$ at one year compared to $\sim 30 \%$ at 3.5 years after study initiation. Notably, additional late boosts that were administered to HIV-uninfected RV144 vaccinees yielded only a short-lived increase of Ab titers to gp120 and V1V2 after the first additional boost that waned rapidly after the second immunization [128]. The high-risk study population of injecting drug users (IDU) in VAX003 has to be considered as a possible reason for the elevated risk of infection compared to RV144. In contrast, RV144 was conducted in the low-risk heterosexual population of Thailand, and $89 \%$ of infections in RV144 occurred with CRF01_AE strains, which are supposed to inherit a 
naturally more open Env configuration [129]. Moreover, boosting in RV144 was performed with a slightly modified gp120 protein (N-terminal 11 aa deletion, replaced with a gD protein-derived tag) of the highly immunogenic A244 strain, which led to the exposure of V2i and V2p epitopes for efficient elicitation of both $\mathrm{Ab}$ classes [130]. The qualitatively different $\mathrm{V} 2 \mathrm{Ab}$ immune response in RV144 compared with VAX003 might have been due to the usage of a gp160 DNA prime in a canarypox vector, the more immunogenic CRF01_AE A244 and TH023 antigens, and a better sequence match between the immunogens and the regionally prevalent challenge viruses in RV144 [108,130,131].

\subsection{Alternative Correlates of RV144 Vaccine Efficacy with or without the Contribution of V2}

One of the most puzzling findings of RV144 has been the identification that high Env-specific plasma IgA levels were associated with an enhanced risk of infection. Plasma IgA Abs were shown to interfere with functional IgG Abs directed against key epitope regions in RV144, such as $\mathrm{C} 1[2,121,125,132]$. The importance of functional $\mathrm{F}_{\mathrm{c}} \gamma$-receptors in Ab-mediated protection of SHIV infection is well known [133]; however, ADCC and antibody-dependent cellular phagocytosis (ADCP) have only rarely been identified as an immune correlate of protection in recent macaque challenge experiments (Table 3). Notably, Fc $\gamma$-phenotyping revealed that single-nucleotide polymorphisms (SNP) in the Fc $\gamma$ R2C gene (CT and TT) conferred 91\% vaccine efficacy against K169 viruses in RV144 compared to a $15 \%$ vaccine efficacy in individuals with a different SNP (CC) [134]. Of interest, these SNPs are more prevalent in Africa compared to Thailand, which may affect vaccine efficacy in this arm of protection in the upcoming vaccine trials in South Africa [135]. In addition to host factors and $\mathrm{Ab}$-mediated effector functions, functional $\mathrm{CD}^{+} \mathrm{T}$ cell responses have been associated with inferred risk. Specifically, Env-specific poly-functional $\mathrm{CD}^{+}$effector memory $\mathrm{T}$ cells with the capacity to produce multiple cytokines, such as CD40L, IL-2, IL-4, IFN- $\gamma$ and TNF- $\alpha$ were identified as a strong beneficial factor. Dominant IFN- $\gamma$ responses were identified in CD4 ${ }^{+}$T cells stimulated with CRF01_AE $\mathrm{V} 2$ peptides $[2,136]$. These data suggest that a concerted interplay of vaccine-induced humoral, cellular, cytokine, and host factors was responsible for the partial vaccine efficacy in RV144.

\subsection{Translation of RV144 Findings into the Development of Future Human Vaccine Trials}

More mechanistic insights into correlates of protection are expected to come from the running vaccine trials in South Africa, i.e., HIV Vaccine Trials Network (HVTN) 702 and HVTN 705/HPX2008 (Table 2). HVTN 705/HPX2008 applies mosaic HIV immunogens with the goal to induce immune responses capable of recognizing diverse globally circulating viral variants. The preparatory Phase I/IIa APPROACH study yielded robust humoral and cellular immune responses, comparable to ones in a matched rhesus macaque challenge study, which achieved $67 \%$ protection from SHIV acquisition [137]. HVTN 702 is a further development of RV144 in which the immunogens were adapted to the circulating clade C strains in South Africa, and the adjuvant was changed to MF59 to increase immunogenicity. The vaccine trial will help to clarify whether the increased immunogenicity of MF59 will prove beneficial in humans or whether the vaccine-elicited innate and adaptive immune responses will be skewed towards less protective phenotypes as observed in a recent SIV vaccination study in macaques (Section 4.2) [73]. The preparatory HVTN 100 Phase I/IIa study (same protocol as HVTN 702, applied to a smaller number of participants) achieved strong and cross-reactive IgG binding responses, which qualified the regimen for efficacy testing in the successive Phase $\mathrm{Ilb} / \mathrm{III}$ trial. V1V2 binding responses were lower in magnitude and positivity compared to RV144 and also to HVTN 097, a Phase I study designed to evaluate the RV144 regimen in South Africans [138-140]. Fc-mediated effector functions, e.g., ADCP on V1V2 coated beads were also lower in magnitude, which highlighted the importance of the insert sequence for vaccine-elicited $\mathrm{Ab}$ immune responses. 
Table 2. Human HIV-1 vaccine efficacy trials and outcome.

\begin{tabular}{|c|c|c|c|c|c|c|c|c|c|}
\hline \# & Trial & Vaccine & Year & $\begin{array}{l}\text { Location/Clades/Target } \\
\text { Population }\end{array}$ & Study Number & Ref & Result/Protection & Immune Correlates & V2 Ab Response \\
\hline I & VAX003 & $\begin{array}{l}\text { AIDSVAX } \\
\text { B/01_AE } \\
\text { Gp120 }\end{array}$ & 2003 & $\begin{array}{l}\text { Thailand } \\
\text { IDU }\end{array}$ & 2546 & [118] & No efficacy & - & $\begin{array}{l}\text { Yes, RV144-like, peak Ab } \\
\text { responses after 3-4 } \\
\text { immunizations, but } \\
\text { waning after 5-7 } \\
\text { immunizations; relative } \\
\text { enhancement of IgG2 and } \\
\text { IgG4 responses with } \\
\text { limited antiviral } \\
\text { functionality }\end{array}$ \\
\hline II & VAX004 & $\begin{array}{l}\text { AIDSVAX } \\
\text { B/B } \\
\text { Gp120 }\end{array}$ & 2003 & $\begin{array}{l}\text { USA, Canada, Puerto } \\
\text { Rico, Netherlands } \\
\text { MSM }\end{array}$ & 5417 & [119] & No efficacy & - & $\begin{array}{l}\text { Yes, lower frequency and } \\
\text { titers compared to VAX003 } \\
\text { and RV144 }\end{array}$ \\
\hline III & STEP & $\begin{array}{l}\text { MRK-Ad5 B } \\
\text { gag, pol, nef } \\
\text { (T-cell based) }\end{array}$ & 2007 & $\begin{array}{l}\text { North America, the } \\
\text { Caribbean, South } \\
\text { America, Australia } \\
\text { MSM }\end{array}$ & 3000 & [116] & $\begin{array}{l}\text { No efficacy; Immunizations } \\
\text { halted; potential for increased } \\
\text { risk of HIV infection among } \\
\text { Ad5-seropositive, } \\
\text { uncircumcised men. }\end{array}$ & - & $\begin{array}{l}\text { No } \\
\text { (no Env in vaccine) }\end{array}$ \\
\hline IV & Phambili & $\begin{array}{l}\text { MRK-Ad5 } \\
\text { B } \\
\text { gag, pol, nef (T-cell } \\
\text { based) }\end{array}$ & 2007 & $\begin{array}{l}\text { South Africa } \\
\text { heterosexual }\end{array}$ & $\begin{array}{l}801 \\
\text { (3000 were planned) }\end{array}$ & [117] & $\begin{array}{l}\text { Immunizations halted after } \\
\text { eight months based on STEP } \\
\text { trial result. } \\
\text { No efficacy at this point }\end{array}$ & - & $\begin{array}{l}\text { No } \\
\text { (no Env in vaccine) }\end{array}$ \\
\hline $\mathrm{V}$ & $\begin{array}{l}\text { Thai Prime-Boost/ } \\
\text { RV } 144\end{array}$ & $\begin{array}{l}\text { ALVAC-HIV (vCP1521) } \\
\text { 01_AE (TH023), } \\
\text { AIDSVAX gp120/alum } \\
\text { B/01_AE (MN/A244) }\end{array}$ & 2009 & $\begin{array}{l}\text { Thailand } \\
\text { Heterosexual, high risk }\end{array}$ & 16,402 & {$[2,3,7]$} & $\begin{array}{l}\text { Yes, } \\
31.2 \% \text { efficacy after } 3.5 \text { y } \\
(60.5 \% \text { after } 1 \text { y) }\end{array}$ & $\begin{array}{l}\text { High titers of V2i and V2p } \\
\text { Abs, } \\
\text { ADCC in combination with } \\
\text { low Env-specific IgA in } \\
\text { plasma, viruses with K169 } \\
\text { and mismatch at I181 }\end{array}$ & $\begin{array}{l}\text { Yes, } \\
\text { strong IgG1 and IgG3 } \\
\text { responses associated with } \\
\text { polyfunctional responses; } \\
\text { strong immunogenicity of } \\
\text { 01_AE strain A244 }\end{array}$ \\
\hline VI & HVTN 505 & $\begin{array}{l}\text { DNA } \\
\text { gag, pol, nef, env A/B/C, } \\
\text { rAd5 gag-pol B, env } \\
\text { A/B/C }\end{array}$ & 2013 & $\begin{array}{l}\text { USA } \\
\text { MSM }\end{array}$ & 2500 & [120] & $\begin{array}{l}\text { No efficacy; Immunizations } \\
\text { halted; no prevention of HIV } \\
\text { infection nor reduction of viral } \\
\text { load among vaccine recipients } \\
\text { who became HIV infected. }\end{array}$ & - & Low titers and frequency \\
\hline VII & $\begin{array}{l}\text { HVTN702 } \\
\text { (The Uhambo Study) }\end{array}$ & $\begin{array}{l}\text { RV144-like, } \\
\text { ALVAC-HIV (vCP2438) } \\
\text { C (96ZM651), } \\
\text { bivalent gp120/MF59 C } \\
\text { (TV1 and 1086) }\end{array}$ & $\begin{array}{l}\text { Ongoing, } \\
\text { 2016-2021 }\end{array}$ & $\begin{array}{l}\text { South Africa } \\
\text { adults }\end{array}$ & 5400 & https://c & nicaltrials.gov/ct2/show/NCT029e & 8849 & \\
\hline VIII & $\begin{array}{l}\text { HVTN 705/HPX2008 } \\
\text { (The Imbokodo Study) }\end{array}$ & $\begin{array}{l}\text { Ad26 Mosaic (4x) HIV } \\
\text { (gag, pol, env), } \\
\text { gp140/alum } \\
\text { protein C }\end{array}$ & $\begin{array}{l}\text { Ongoing, } \\
\text { 2017-2022 }\end{array}$ & $\begin{array}{l}\text { South Africa } \\
\text { women }\end{array}$ & 2600 & https://c & nicaltrials.gov/ct2/show/NCT030 & 0629 & \\
\hline
\end{tabular}


In view of the upcoming vaccine trials, the viral diversity in a study population may have a significant impact on vaccine efficacy. As such, the CRF01_AE diversity in Thailand was less pronounced than the clade $C$ diversity in South Africa. Interestingly, the similarity between the clade C protein boost sequences (1086 and TV-1) in HVTN 100 and HVTN 702 and the circulating strains in South Africa is $\sim 8 \%$ more distant from each other than the respective RV144 immunogens and prevalent strains in Thailand [141]. On the contrary, South African clade C viruses have a higher frequency of $\alpha 4 \beta 7$-sensitive sequences compared to other clades/geographic regions but the consequences with regards to vaccine efficacy remain to be determined (Section 5) [142]. Regarding the regionally and globally evolving HIV-1 diversity, immunogen sequence adaptations may need to consider the regional predominance of circulating strains as well as the chronological phasing of vaccine trials $[9,56]$.

\section{The Impact of V1V2-Specific Abs in NHP Experiments}

\subsection{Passive Immunization Experiments}

The passive transfer of Abs to animals followed by virus challenge(s) is a well-established method to determine their antiviral functions. Such experiments have demonstrated that Abs against HIV-1 Env are critical for the protection against HIV-1 [143-145], SIV [146], and SHIV [147,148].

To test the protective function of weakly-/non-neutralizing anti-V2 mAbs, a single V2i mAb was administered to rhesus macaques with subsequent mucosal SHIV BaL.P4 challenge [149]. The tested mAb, 830A, weakly neutralized 4 of 41 analyzed tier 1 pseudoviruses with $\mathrm{IC}_{50}$ ranging from 0.4 to 36 $\mu \mathrm{g} / \mathrm{mL}$ [35]. Passive transfer of $830 \mathrm{~A}$ mAb resulted in reduced plasma viral load and virus levels in peripheral blood mononuclear cells (PBMCs) and decreased viral DNA in lymphoid tissues, but did not significantly reduce the number of infected animals (5/18 protected or tightly controlled) compared to the dengue virus control mAb [149].

These results are similar to three passive immunization experiments in rhesus macaques that tested the protective functions of non-neutralizing mAbs. Whereas a combination of neutralizing mAbs, 2G12, 2F5 and 4E10, specific to gp120 high mannose carbohydrates and gp41, prevented $\mathrm{SHIV}_{\mathrm{SF} 162 \mathrm{P} 3}$ vaginal transmission, the non-neutralizing gp41 mAbs 246-D and 4B3 reduced plasma viral load but had no impact on SHIV acquisition [150]. Another study revealed that neutralizing anti-CD4bs mAb b12 provided sterilizing immunity against $\mathrm{SHIV}_{\mathrm{SF} 162 \mathrm{P} 4}$ challenge in seven of seven macaques, while the non-neutralizing CD4bs mAb b6 did not protect any of the five studied animals. Non-neutralizing anti-gp41 mAb F240 achieved protection in two of five passively immunized animals, thus yielding a limited but overall non-significant reduction of infected animals [151]. The third study demonstrated that two non-neutralizing mAbs, 7B2 (anti-gp41) and A32 (anti-C1), administered passively to rhesus macaques did not protect against $\mathrm{SHIV}_{\mathrm{BaL}}$ virus infection, contrary to control $\mathrm{mAb}$ CH22 (anti-V3), which prevented infection in 4 of 6 animals [152]. These four passive immunization experiments indicate that non-neutralizing HIV-1 mAbs, including anti-V2 mAbs, do not achieve significant protection against virus challenge; however, they can reduce viral load.

In contrast to non-neutralizing Abs, many bnAbs effectively protected rhesus macaques from SHIV infection in a dose-dependent manner, including cases of sterilizing immunity with a single intravenous dose. High efficacies have been reported for engineered bi- and tri-specific bnAb constructs and for bnAbs targeting the CD4bs, the MPER region, the outer domain glycans, the V3 glycan, and the V2 apex region [78,147,148,153-162]. Among V2 bnAbs, PG9 (V2q), PGDM1400 and CAP256-VRC26.25-LS (both V2qt) have been tested for their protective capacity $[159,162]$. PG9 achieved only partial protection against the tier 1 virus $\mathrm{SHIV}_{\text {BaL.P4 }}$ at $5 \mathrm{mg} / \mathrm{kg}$, despite a mean neutralization IC50 of $0.06 \mathrm{mg} / \mathrm{mL}$ against the same virus, whereas VRC01 and 10E8 were fully protective at the same Ab concentration [159]. In contrast, complete protection against a single high dose challenge with tier $2 \mathrm{SHIV}_{325 \mathrm{c}}$ was achieved at low serum $\mathrm{Ab}$ concentrations $<0.75 \mathrm{mg} / \mathrm{mL}$ for V2qt mAb CAP256-VRC26.25-LS [162].

Despite the promising results of many passive bnAb SHIV protection studies and a report on vaccine-induced protection from homologous SHIV challenges, which depended on serum $\mathrm{nAb}$ 
titers [163], it is not yet clear whether nAb titers define protection in the heterologous setting of active immunization. Additionally, infections have been observed despite potent neutralization responses of serum antibodies against breakthrough viruses [164]. Besides neutralization per se, Fc-mediated functions play an essential role in Ab protection against HIV infection [133]. There is significant overlap between the capacities of Abs to mediate ADCC against HIV-infected cells and to neutralize viral infection [165-168]. However, Fc-mediated functions may be partially redundant for very potent bnAbs [169], and ADCC can be uncoupled from neutralization for Abs with low-affinity binding to Env [170]. Though bnAbs have entered the stage of clinical testing, it is not yet known to what extent they can confer protection from HIV-1 infection in humans. Ongoing passive vaccination trials, which are most advanced for CD4bs bnAbs VRC01 (HVTN 703/HPTN 081 and HVTN 704/HPTN 085) and 3BNC117 will provide more information about the protective potential of bnAbs in humans [87].

\subsection{Vaccine Protection Experiments}

Protection experiments in rhesus macaques are important pre-clinical studies to test the efficacy of candidate HIV vaccines. Experiments using SHIV as a challenging virus are the closest model for evaluating the potential of candidate HIV vaccines to generate protective Ab responses in NHPs. The SIV model is more distant from the human system but provides useful data for immune correlate analyses. Some of these NHP experiments analyzed the relationship between the level or titer of vaccine-induced anti-V2 Abs and the outcome of viral infection.

Only one of six SHIV studies identified a correlation between higher anti-V2 Ab titers and viral control. V2 Ab binding significantly correlated with viral control in the arm where animals were immunized with the replicating adenovirus (SAd7) vector (40\% protection), but not in the arm using non-replicating Ad4 (30\% protection) [171]. Several other HIV Env/SHIV studies also achieved partial protection of the immunized rhesus macaques against SHIV challenge, which was in the range between $18 \%$ and $67 \%$. However, a correlation between anti-V2 Abs and reduced virus acquisition was not observed $[101,105,137,172]$. The immune correlates differed in each study and included titers of Abs to homologous and heterologous Env proteins (gp120 and gp140), neutralization of $\mathrm{HIV}_{\mathrm{SF162}}$, Env-specific CD4 ${ }^{+} \mathrm{T}$ cell responses, ADCC, phagocytosis, and MIP-1 $\beta$ in NK cells (Table 3). Though not protective against $\mathrm{SHIV}_{\mathrm{SF} 162 \mathrm{P} 3}$ challenges, a recent study employed sublingual/buccal and intradermal/subcutaneous immunizations with MVA-HIV DNA and trimeric cycP-gp120 boosts, which significantly delayed the acquisition of infection compared to controls. Strong IgG responses were elicited in serum and mucosal tissues, including broad gp70-V1V2 responses against multiple HIV-1 clades and subdominant V2p responses. Correlates of delayed infection were non-neutralizing $\mathrm{Ab}$ effector functions and Env-specific CD4 ${ }^{+}$T-cell responses [173]. Comparably, HIV C.1086 gp140 protein boosts following DNA/MVA vaccination strongly enhanced autologous V1V2-specific immune responses, but they lacked binding to heterologous V1V2 and efficacy against heterologous tier 2 clade C $\mathrm{SHIV}_{1157 i p d 3 N 4}$ challenge [174].There is one macaque challenge study, which selectively tackled the role of V2i and V2p Abs. Rhesus macaques were co-immunized with V1V2-TH023 DNA, V1V2-A244-2F5K, and V1V2-CaseA2-2F5K fusion proteins, and additionally with cyclic V2-CaseA2 peptides. Two weeks after the last immunization, the animals were challenged with intra-rectal administration of

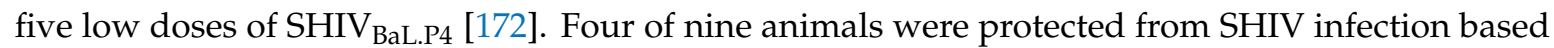
on undetectable plasma viral load (PVL) and virus DNA in PBMCs and lymph nodes. Plasma Abs

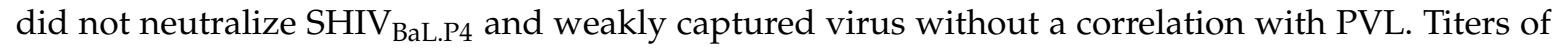
plasma anti-V2 Abs tested against eight V1V2 fusion proteins and cyclic V2 peptides were high in protected and infected animals without significant differences. In addition to V2 binding, ADCC and phagocytosis were comparable between protected and infected animals and did not correlate with the acquisition of SHIV $\mathrm{BaL}_{\text {B.P }}$ suggesting that V1V2-directed immunizations can confer partial vaccine efficacy but anti-V2 Abs may not be independently involved in controlling SHIV virus challenge.

Protection experiments using the SIV Env/SIV challenge model yielded an Ab response that particularly focused on V2. Nine protection experiments were performed in rhesus macaques, 
which analyzed the titer or level of anti-V2 Abs induced by the SIV Env vaccine towards an SIV challenge. A correlation between titers/levels of anti-V2 Abs and reduced risk of virus infection was common [73,175-182]. Other potential immune correlates were also determined, including anti-Env (gp120, gp140, or cell-bound Env) Abs, Env-specific T cell responses, neutralization, and activation of $\mathrm{CD}^{+}$monocytes and mucosal NKp44+IL17 cells (Table 3). In one of these studies, a correlation with reduced risk of infection was found for anti-V2 Abs in mucosal secretions, but not in serum [177].

Another study used an RV144-like regimen to compare alum, as used in RV144, with the more immunogenic MF59 adjuvant, which is employed in the ongoing HVTN 702 vaccine trial in South Africa. Compared to alum, MF59 induced stronger systemic and mucosal humoral and cellular Env-specific immune responses, both in magnitude and in function (including neutralization, ADCC, and phagocytosis). Surprisingly, only vaccinations with alum reduced the risk of infection (44\% vaccine efficacy), which correlated with mucosal anti-V2 Ab levels, whereas vaccinations with MF59 did not achieve significant viral control [73]. Notably, MF59-induced mucosal levels of anti-V2 IgG even correlated with an increased risk of virus acquisition. Between animals of the alum and MF59 arm, differences in Ab glycoforms were detected that are known to impact ADCC and complement activation. These data suggested critical differences in $\mathrm{Ab}$ effector functions among antibodies with apparently similar specificities. [73]. In addition to adaptive V2 IgG responses, vaccine efficacy correlated with alum-induced, but not with MF59-induced, Env-specific mucosal innate immune responses. These findings displayed the importance of a fine-balanced interplay between different arms of immunity. The strong dominance of anti-V2 Abs and correlations with viral control in the SIV Env/SIV challenge model supposedly depend on the higher immunogenicity/accessibility of the V2 region in SIV relative to HIV-1. As mentioned in Section 2.2, the SIV V2 region contains a pair of V2 cysteine residues at positions 183 and 191, which plays a role in stabilizing the Env trimer (Figure 2) [183]. Vaccinations of NHPs with SIVmac239 or SIVsmE660 Env antigens induce significantly higher levels of anti-V2 Abs than immunizations with HIV-1 Env including sequences of strains TH023, MN, 1086, ZM651, and A244 [69]. Several studies which observed a correlation between $\mathrm{V} 2 \mathrm{Ab}$ levels/titers and protection from infection suggested that anti-V2 Abs may serve as a surrogate marker for other immune responses $[137,175,181]$. Studies of natural infection further indicated that the level or titer of anti-V2 plasma Abs could be a marker of an HIV-infected individual's overall ability to mount $\mathrm{Ab}$ responses to Env proteins [19]. Experimental proof with mechanistic explanations for these hypothesis has yet to be provided. Immunizations with SIV appear well-suited to study V1V2-focused immune responses and associated correlates of protection based on the more constrained, and presumably more exposed V1V2 region. These features, however, make SIV significantly different from SHIV/HIV and need to be considered when evaluating experiments with SIV as challenge virus. 
Table 3. Non-human primate vaccine studies with SHIV or SIV challenges.

\begin{tabular}{|c|c|c|c|c|c|c|c|}
\hline \# & Author & Immunization & Challenge & $\%$ Protection & Immune Correlates & V2 Antigens Tested & V2 Abs Correlation \\
\hline \multicolumn{8}{|c|}{ HIV Env } \\
\hline 1 & $\begin{array}{l}\text { Barouch DH } \\
\text { Cell, } 2013\end{array}$ & Ad/MVA (mosaic) & $\mathrm{SHIV}_{\mathrm{SF} 162 \mathrm{P} 3}$ & $\begin{array}{l}3 \text { chall. } 45 \% \\
6 \text { chall. } 18 \%\end{array}$ & $\begin{array}{l}\text { Env Abs } \\
\text { Neutral SF162, ADCP }\end{array}$ & $\begin{array}{l}\text { V2 peptides } \\
\text { V1V2-gp70 }\end{array}$ & $\mathrm{NO}$ \\
\hline 2 & $\begin{array}{l}\text { Bradley T } \\
\text { Nat Comm, } 2017\end{array}$ & $\begin{array}{l}\text { ALVAC/Pentavalent } \\
\text { (B and AE clade) }\end{array}$ & $\begin{array}{l}\text { SHIV }_{1157} \\
\text { (clade C) }\end{array}$ & $55 \%$ & $\begin{array}{l}\text { Cell-bound Env Abs, } \\
\text { ADCC MIP-1b in NK cells }\end{array}$ & V2 peptides & NO \\
\hline 3 & $\begin{array}{l}\text { Barouch DH } \\
\text { Lancet } 2018\end{array}$ & $\begin{array}{l}\text { Ad26, gp140 } \\
\text { mosaic }\end{array}$ & $\mathrm{SHIV}_{\mathrm{SF} 162 \mathrm{P} 3}$ & $67 \%$ & $\begin{array}{l}\text { Env Abs } \\
\text { T-cell response }\end{array}$ & V1V2-gp70 & $\mathrm{NO}$ \\
\hline 4 & $\begin{array}{l}\text { Malherbe DC } \\
\text { J. Virol., } 2018\end{array}$ & $\begin{array}{l}\text { Replicating SAd7 } \\
\text { Non-replicating Ad4 (1086, clade } \\
\text { C) }\end{array}$ & SHIV $_{157 i p E L}$ & $\begin{array}{l}\text { Sad- }-40 \% \\
\text { Ad } 4-30 \%\end{array}$ & V2 Abs (SAd7) & $\begin{array}{l}\text { V1V2 recombinant } \\
\text { (1086.C, JRFL, AE244, } \\
\text { 14/00/4) }\end{array}$ & $\begin{array}{l}\text { YES-SAd7 } \\
\text { NO-Ad4 }\end{array}$ \\
\hline 5 & $\begin{array}{l}\text { Hessell A/Gorny MK } \\
\text { (Keystone abstract 2019) }\end{array}$ & $\begin{array}{l}\text { DNA gp160, AE } \\
\text { gp120, clade AE, B }\end{array}$ & SHIV $_{\text {BaL.P4 }}$ & $55 \%$ & $\begin{array}{l}\text { SHIV capture Abs } \\
\text { Neutral. HIV-SF162 }\end{array}$ & $\begin{array}{l}\text { V1V2 scaffolds } \\
\text { V2 peptides (CaseA2, } \\
\text { AE244, 1086, ZM109) }\end{array}$ & NO \\
\hline 6 & $\begin{array}{l}\text { Hessell A/Gorny MK } \\
\text { (Keystone abstract 2019) }\end{array}$ & $\begin{array}{l}\text { DNA V1V2, AE } \\
\text { V1V2 scaffolds, AE, B }\end{array}$ & SHIV $_{\text {BaL.P4 }}$ & $45 \%$ & Not determined yet & $\begin{array}{l}\text { V1V2 scaffolds } \\
\text { V2 peptides (CaseA2, } \\
\text { AE244, 1086, ZM109) }\end{array}$ & $\mathrm{NO}$ \\
\hline \multicolumn{8}{|c|}{ SIV Env } \\
\hline 7 & $\begin{array}{l}\text { Barouch DH } \\
\text { Nature, } 2012\end{array}$ & $\begin{array}{l}\text { Ad/poxvirus } \\
\text { SIVsmE543 }\end{array}$ & $\begin{array}{l}\text { SIVmac251 } \\
\text { grown in human cells }\end{array}$ & $80 \%$ & Env Abs & V2 peptide & YES \\
\hline 8 & $\begin{array}{l}\text { Roederer M } \\
\text { Nature } 2014\end{array}$ & $\begin{array}{l}\text { DNA/Ad5 } \\
\text { SIVmac239 }\end{array}$ & SIVmac660 & $\begin{array}{l}\text { Vaccine efficacy: } \\
69 \% \text { (mac239) }\end{array}$ & $\begin{array}{l}\text { Env Abs (C3, CD4bs) } \\
\text { Neutralization }\end{array}$ & V1V2mac239 & YES \\
\hline 9 & $\begin{array}{l}\text { Singh S. } \\
\text { J. Virol. } 2018\end{array}$ & $\begin{array}{l}\text { DNA, gp120 } \\
\text { SIVmac251 }\end{array}$ & SIVsmE660 & $0 \%$ & $\begin{array}{l}\text { Neutral. SIVsm660 } \\
\text { T cells response }\end{array}$ & $\begin{array}{l}\text { V1V2-gp70 } \\
\text { SIVmac251, smE660 }\end{array}$ & $\begin{array}{l}\text { YES } \\
\text { Mucosal V2 Abs }\end{array}$ \\
\hline 10 & $\begin{array}{l}\text { Pegu P. } \\
\text { J. Virol. } 2013\end{array}$ & $\begin{array}{l}\text { ALVAC, gp120 } \\
\text { SIVmac251 }\end{array}$ & SIVmac251 & $\begin{array}{l}27 \% \\
(3 \text { of } 11)\end{array}$ & Env Abs avidity & $\begin{array}{l}\text { V2 peptides } \\
\text { SIVmac251 }\end{array}$ & YES \\
\hline 11 & $\begin{array}{l}\text { Gordon SN. } \\
\text { J. Immunol. } 2014\end{array}$ & $\begin{array}{l}\text { HPV, ALVAC, } \\
\text { gp120 SIVmac251 }\end{array}$ & SIVmac251 & $25 \%$ & Env-T cells & $\begin{array}{l}\text { V1V2 mini protein } \\
\text { SIVmac239 }\end{array}$ & YES \\
\hline 12 & $\begin{array}{l}\text { Gordon SN } \\
\text { J. Immunol. } 2016\end{array}$ & $\begin{array}{l}\text { ALVAC, gp120 } \\
\text { SIVmac251 }\end{array}$ & SIVmac251 & $44 \%$ & Only V2 Abs & $\begin{array}{l}\text { V1V2-gp70 } \\
\text { V2 peptides } \\
\text { SIVmac251, smE543 }\end{array}$ & $\begin{array}{l}\text { YES } \\
\text { mucosal V2 Abs-Yes } \\
\text { serum V2 Abs-No }\end{array}$ \\
\hline 13 & $\begin{array}{l}\text { Kwa S } \\
\text { J. Virol. } 2015\end{array}$ & $\begin{array}{l}\text { CD40L DNA } \\
\text { MVA SIVmac239 }\end{array}$ & SIVmac251 & $50 \%$ & $\begin{array}{l}\text { V2p Abs, gp41 Abs, V1 } \\
\text { Abs, gut CD8 T cells }\end{array}$ & V2 peptides & $\begin{array}{l}\text { YES } \\
\text { Serum V2p Abs }\end{array}$ \\
\hline 14 & $\begin{array}{l}\text { Vaccari M. } \\
\text { Nat Med, } 2016\end{array}$ & $\begin{array}{l}\text { ALVAC, gp120 } \\
\text { SIVmac251 } \\
\text { (alum, MF59) }\end{array}$ & SIVmac251 & $\begin{array}{l}44 \% \text { (alum) } \\
0 \% \text { (MF59) }\end{array}$ & $\begin{array}{l}\text { Mucosal NKp44+IL17 } \\
\text { (alum) }\end{array}$ & $\begin{array}{l}\text { V1V2-gp70 } \\
\text { V2 peptides } \\
\text { SIVmac239, 251, smE660 }\end{array}$ & $\begin{array}{l}\text { YES (Alum, mucosal V2) } \\
\text { NO (MF59, mucosal V2 } \\
\text { increased risk) }\end{array}$ \\
\hline 15 & $\begin{array}{l}\text { Vaccari M } \\
\text { Nat Med, } 2018\end{array}$ & $\begin{array}{l}\text { ALVAC, DNA, } \\
\text { Ad26 + gp120 } \\
\text { SIVmac251, smE660 }\end{array}$ & SIVmac251 & $\begin{array}{l}52 \% \\
\text { DNA and ALVAC }\end{array}$ & Activation CD14 monocytes & $\begin{array}{l}\text { V2 peptides } \\
\text { SIVmac251, smE543 }\end{array}$ & YES \\
\hline
\end{tabular}




\section{5. $\alpha 4 \beta 7$-Blocking by V2-Specific Abs}

$\mathrm{V} 2 \mathrm{p}$, and to a lesser extent V2i Abs, have the unique feature of binding an epitope region, which encompasses the $\alpha 4 \beta 7$ integrin binding site. The integrin $\alpha 4 \beta 7$ mediates homing of immune cells, including highly HIV-susceptible $\mathrm{CD}^{+}{ }^{+} \mathrm{T}$ cell subsets to the gastrointestinal tract, which is one of the primary sites of HIV and SIV pathogenesis [184-190]. HIV Env has been shown to bind to and signal through $\alpha 4 \beta 7$ via a conserved tripeptide LDI/V motif in V2 (aa 179-181) (Figures 2 and 3) [191], presumably complemented by secondary binding motifs (e.g., aa 170-173) and unspecific binding mechanisms [192-194]. Importantly, $\alpha 4 \beta 7$ serves as an attachment factor for HIV and not as an entry receptor, and $\alpha 4 \beta 7$ blocking does not neutralize HIV-1 infection [191]. Considering the fact that $\alpha 4 \beta 7$-Env binding is not a general feature of all HIV strains [142,195-197], $\alpha 4 \beta 7$ expression on peripheral $\mathrm{CD} 4^{+} \mathrm{T}$ cells predicts HIV acquisition and disease progression as measured by the increased rates of $\mathrm{CD}^{+}{ }^{+} \mathrm{T}$ cell decline and higher viral loads [198]. Furthermore, the frequency of $\alpha 4 \beta 7$-high memory CD4 ${ }^{+} \mathrm{T}$ cells correlated with susceptibility to rectal SIV infection [199]. $\alpha 4 \beta 7$ increased HIV susceptibility in activated $\mathrm{CD}^{+} \mathrm{T}$ cells in an HIV attachment-independent manner [200].

Based on the physiological functions and clinical relevance of the attachment and signaling factor $\alpha 4 \beta 7$ on $\mathrm{CD}^{+} \mathrm{T}$ cells, a steric blockade of the $\alpha 4 \beta 7$-gp120/V2 interaction was suggested as a promising target for drug and Ab therapies, and active vaccinations via induction of blocking V2 Abs [197,201,202]. This led to the hypothesis that anti-V2 Abs in vivo block viral adhesion and subsequent infection of Th17 cells expressing CD4, CCR5, and $\alpha 4 \beta 7[189,191,203]$. This idea received support from a study on anti- $\alpha 4 \beta 7$ treatment in a cohort of individuals with inflammatory bowel disease and concomitant HIV-1 infection. The combinational treatment led to a significant attenuation of lymphoid aggregates, which serve as critical sanctuaries for maintaining viral reservoirs [204]. A primatized anti- $\alpha 4 \beta 7$ $\mathrm{mAb}$ achieved promising results towards virologic control of SIV infection. Blocking $\alpha 4 \beta 7$ during acute intravenous SIV infection reduced plasma and gastrointestinal tissue viral loads [205]. When administered before low-dose repeated vaginal challenge with SIV, anti- $\alpha 4 \beta 7$ yielded protection in half of the studied animals. Treated animals that eventually became infected had a delay in infection and had decreased damage in the gut-associated lymphoid tissue (GALT) with maintained CD4 ${ }^{+} \mathrm{T}$ cell numbers [206]. In another study, SIV-infected rhesus macaques that had received antiretroviral therapy (ART) in combination with anti- $\alpha 4 \beta 7 \mathrm{mAb}$ pACT- 1 had sustained control of viremia in all animals for more than nine months without therapy [207].

By contrast, a humanized version of the same anti- $\alpha 4 \beta 7 \mathrm{mAb}$ (Vedolizumab) neither prevented

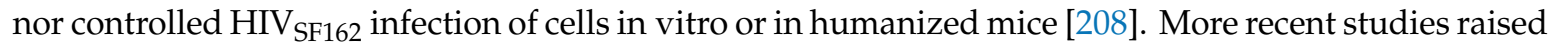
further doubt regarding protective effects mediated by mAbs against $\alpha 4 \beta 7$. Administration of pACT1 ( $\mathrm{mAb}$ agonist of $\alpha 4 \beta 7$ ) or two mAbs against SIV V2 that block $\alpha 4 \beta 7$ binding to Env (ITS09 and ITS12) yielded no consistent virologic control in rhesus macaques post-ART [209]. In a small clinical trial with eight HIV infected individuals on ART (NCT0202788175), none experienced sustained suppression of viral load using humanized vedolizumab (anti- $\alpha 4 \beta 7$ ) after ART interruption [210]. These data suggest that the unusual ability of anti-V2 Abs to inhibit $\alpha 4 \beta 7$ interaction with gp120 is not responsible for controlling viremia. Synergistic immunomodulatory effects have been observed when used in concert with suboptimal doses of bnAb VRC01, which may be used in future combinational therapies [113]. New generation $\alpha 4 \beta 7$-blocking Abs [211] and upcoming vaccine trials in geographic regions with $\alpha 4 \beta 7$-reactive viruses $[142,193,197,212]$ will further illuminate the clinical impact of $\alpha 4 \beta 7$-inhibition in humans.

\section{V1V2-Specific Immune Responses in Natural Infection}

Studies of natural infection provide the opportunity to analyze the development of V1V2 immune responses after sustained viral "priming and boosting" in humans [20,21,213,214]. Moreover, it has been the only platform to delineate the maturation of bnAbs $[29,44,92,94,95,215-217]$. Dissecting polyclonal immune responses and viral epitope signatures in natural infection and vaccinees reveals "humoral footprints" that aid vaccine design $[19,20,111,218-220]$. Since human vaccine trials require extensive 
logistics and financial efforts, animal models are widely used [10-12]. However, in comparison to humans, animal models exhibit incongruences in host and viral genomes, immune repertoires, and overall responsiveness. Furthermore, limitations regarding longitudinal follow-up, availability of challenge viruses and immunogens exist [15-17]. Thus, studies of natural infection have complemented human and NHP vaccine studies, and there is growing evidence of similarities between immune responses after vaccination and natural infection.

Natural HIV-1 infection is characterized by generally dominant V3 and gp120 Ab responses with subordinate V1V2 responses, caused by the lower immunogenicity of V1V2 compared to V3 [19,63]. Mutational Env analyses suggest that the highly immunogenic V3 loop is more flexible than V1V2. This difference is due to the apical location of V1V2 on the trimer with the three V1V2 protomers associated at the symmetry axis until Env transitions into a CD4-induced open conformation [221]. Nevertheless, $\mathrm{V} 2 \mathrm{Ab}$ responses are detectable in most individuals and are largely based on weakly-/non-neutralizing V2i responses [24,35]. A study of a cohort of chronically HIV-infected subjects showed that the level of anti-V2 Abs, though lower in magnitude and with a broader spread, strongly correlated with the levels of Abs against gp120 and gp41. The titer of anti-gp120 Abs was significantly lower in patients with deficient anti-V2 Abs than in donors with high titer and cross-reactive anti-V2 Abs [19]. The comparison of V2-deficient with V2-reactive immune responses indicated that shorter V2 regions with fewer $\mathrm{N}$-glycosylation sites and higher charge more efficiently trigger a strong V2 Ab response [19]. Another study revealed that in chronic infection, V1V2 length and potential number of N-glycosylation sites increased substantially before declining in late-stage infection. [222]. HIV-1 seems to adjust to host immune pressure by increasing V1V2 length and the addition of shielding glycans. The predominance of shorter V1V2 regions during early and late-stage infection may reflect immature or waning host immunity. These hypotheses were supported by another study showing that longer V1V2 regions with higher numbers of potential N-glycosylation sites protected against HIV-specific neutralizing Abs [223]. V2 Ab responses may also differ with age [20,213] and sex [118,122], and immune responses vary significantly between adults and infants. The immunization of adults and infants with the same Env vaccine yielded a higher frequency of IgG3 V2 Ab responses in infants (43\%) compared to adults $(12 \%)$. Also, vaccine-elicited Env-specific IgA responses were far more frequent in adults than in infants [224]. Maternal V1V2-reactive IgG levels either had no impact or were even associated with increased mother-to-child transmission (MTCT) risk [225].

Compared to $\mathrm{V} 2 \mathrm{i}, \mathrm{V} 2 \mathrm{p} \mathrm{Ab}$ responses are less frequent in natural infection (Section 2.2) $[19,20,61,62,226]$. The main reason is the occluded epitope in the closed native trimer, which carries V1V2 in the five-stranded $\beta$-barrel conformation (Figure 3) [226]. Instead, V2p Abs prefer $\alpha$-helical V1V2 conformations as found in open Env trimers or monomers. Nevertheless, rare V2p-like immune responses have been observed in HIV-1-infected individuals, presumably due to the presence of aberrant forms of Env displayed on the surface of viruses or infected cells, inherently more open conformations of certain strains/clades, better V2 accessibility/responsiveness during acute infection, or the breathing of Env between closed and open states [22,63,129,226-229]. Consequently, V2p Abs have been isolated both from vaccinees and from naturally-infected individuals [21,22,31].

In contrast to V2i and V2p Abs, which can be readily induced in natural infection and vaccinees, broadly neutralizing V2q or V2qt Abs have only been identified in a small percentage of HIV-1 infected individuals (Sections 2.3.1 and 2.3.2). Neutralization breadth correlates with viral load and $\mathrm{CD}^{+} \mathrm{T}$ cell decline, which partly explains why bnAbs have no impact on disease progression in natural infection [230]. The generation of bnAbs requires multiple years of $\mathrm{Ab} / \mathrm{Env}$ co-evolution [29,44,92,94,95,215-217] and can involve superinfection [29].

Slower disease progression in natural infection has been associated primarily with host factors, whereas vaccine efficacy is assumed to be associated with humoral responses [9,231]. Recent studies suggest that poly-functional immune responses may be critical both in protection from disease progression and in protection from infection [20,111,218,219]. A recent longitudinal study of an HIV-1 transmission cluster revealed that V2 Ab responses and ADCC (against cells expressing open Env) in 
the presence of low Env-specific plasma IgA/IgG ratios correlated with slower disease progression [20]. With the caveat of the limited sample size, the identified immune correlates of slower disease progression were similar to the immune correlates of reduced risk in RV144. Notably, V2 binding correlated with the presence of residue K169 in the contemporaneous viruses of the study participants suggesting similar viral hotspot regions for the elicitation of functional V2i and V2p Abs in natural infection and after vaccination [20-22,232]. Future studies with higher sample numbers will need to reveal which "humoral and viral fingerprints" in natural HIV-1 infection can be translated into promising vaccine strategies.

\section{Conclusions}

Based on the high plasticity and inter-subtype diversity in the V1V2 region, V2 Ab responses are complex and regionally different. These features may affect the development of an HIV-1 vaccine. $\mathrm{V} 2 \mathrm{q} / \mathrm{V} 2 \mathrm{qt}$ bnAbs are highly potent in neutralizing a broad variety of HIV-1 strains, but it has not been possible to induce such bnAbs by vaccination. While germline targeting approaches with sequential boosting are still too far from achieving sufficient neutralization breadth and potency, passive vaccination or combinational treatment options with V2 bnAbs may be realistic goals for the next years. In contrast, V2i and V2p Abs that are readily induced by vaccination or natural infection have not yet proven to be equipped/linked with sufficient antiviral activity to confer independent protection from HIV-1 infection. The controversy after RV144 regarding the role of anti-V2 Abs is still sustained. While several NHP studies identified that V2i and/or V2p Abs correlate with protection from infection, most of these studies used SIV as challenge virus, which is more constrained and accessible in V1V2 based on additional disulfide bonds. The majority of SHIV studies did not provide such correlations. Notably, preliminary data of a current NHP study showed $45 \%$ protection from SHIV infection after a V1V2-focused DNA prime/protein boost vaccination; however, neither high $\mathrm{V} 2 \mathrm{Ab}$ levels, nor neutralization, ADCC, or ADCP correlated with protection. This and other studies underline the still incomplete picture. It seems V1V2 immunogens can induce partially protective immune responses; however, it is possible that non-specific/innate immune responses are the driving force while V2 Abs serve as a surrogate marker. The ability of V2i and V2p Abs to block $\alpha 4 \beta 7$ has attracted much attention. Animal studies and preliminary clinical data confirmed $\alpha 4 \beta 7$ signaling as a biologically important pathway; however, V2 Abs did not consistently block the acquisition of HIV-1 infection.

Based on the currently available data, an independent role for V2i or V2p Abs in conferring vaccine efficacy seems unlikely. Ongoing studies will need to address whether concerted effects of V2 Abs with other Abs and Ab-mediated or innate immune responses influence vaccine impact. Since the antigenic and immunogenic features of V1V2 differ according to clade, vaccine design may need to include regional adaptations. For example, CRF01_AE strains were suggested to inherit a naturally more open Env conformation as compared to most other clades, and thus may be more prone to Ab-mediated clearance. Additionally, CRF02_AG infected individuals were reported to exhibit a similar immunologic pattern of V1V2 responses to those observed in RV144 participants to be associated with slower disease progression. In contrast, V1V2 were shown to be less immunogenic in clades B and C. While SHIV challenge experiments in NHP, including both active vaccinations and passive transfer of V2 Abs, did not provide evidence for a protective role of these Abs, further vaccine studies in humans currently underway will help to determine whether V2-specific Abs can contribute to protection from HIV-1 acquisition and which regional/clade-specific differences should be taken into account for the design of a presumably regional HIV vaccine.

Author Contributions: R.D. prepared the original draft of the paper and generated the figures and tables; R.D. and M.K.G. wrote, reviewed, and edited the paper.

Funding: This work was supported by the grant AI083142 (RD) from the National Institute of Allergy and Infectious Diseases (NIAID), grant TW009604 (RD, MKG) from the Fogarty International Center (FIC), National 
Institutes of Health (NIH), and by the grant AI112546 (MKG) from the National Institute of Allergy and Infectious Diseases (NIAID).

Acknowledgments: The authors thank Flavia Camacho for administrative and technical support and Michelle B. Ryndak for proofreading/copyediting of the manuscript.

Conflicts of Interest: The authors declare no conflict of interest. The funders had no role in the design of the article, analyses, interpretation of data, writing of the manuscript, or the decision to publish the data.

\section{References}

1. UNAIDS. Global AIDS Update 2018-Miles to Go. 2018. Available online: https://www.unaids.org/sites/ default/files/media_asset/miles-to-go_en.pdf (accessed on 27 June 2019).

2. Haynes, B.F.; Gilbert, P.B.; McElrath, M.J.; Zolla-Pazner, S.; Tomaras, G.D.; Alam, S.M.; Evans, D.T.; Montefiori, D.C.; Karnasuta, C.; Sutthent, R.; et al. Immune-correlates analysis of an HIV-1 vaccine efficacy trial. N. Engl. J. Med. 2012, 366, 1275-1286. [CrossRef] [PubMed]

3. Rerks-Ngarm, S.; Pitisuttithum, P.; Nitayaphan, S.; Kaewkungwal, J.; Chiu, J.; Paris, R.; Premsri, N.; Namwat, C.; de Souza, M.; Adams, E.; et al. Vaccination with ALVAC and AIDSVAX to prevent HIV-1 infection in Thailand. N. Engl. J. Med. 2009, 361, 2209-2220. [CrossRef] [PubMed]

4. Desrosiers, R.C. Protection against HIV Acquisition in the RV144 Trial. J. Virol. 2017, 91. [CrossRef] [PubMed]

5. Gilbert, P.B.; Berger, J.O.; Stablein, D.; Becker, S.; Essex, M.; Hammer, S.M.; Kim, J.H.; Degruttola, V.G. Statistical interpretation of the RV144 HIV vaccine efficacy trial in Thailand: A case study for statistical issues in efficacy trials. J. Infect. Dis. 2011, 203, 969-975. [CrossRef] [PubMed]

6. Zolla-Pazner, S.; Gilbert, P.B. Revisiting the Correlate of Reduced Hiv Infection Risk in the Rv144 Vaccine Trial. J. Virol. 2019. [CrossRef] [PubMed]

7. Rolland, M.; Edlefsen, P.T.; Larsen, B.B.; Tovanabutra, S.; Sanders-Buell, E.; Hertz, T.; deCamp, A.C.; Carrico, C.; Menis, S.; Magaret, C.A.; et al. Increased HIV-1 vaccine efficacy against viruses with genetic signatures in Env V2. Nature 2012, 490, 417-420. [CrossRef]

8. Corey, L.; Gilbert, P.B.; Tomaras, G.D.; Haynes, B.F.; Pantaleo, G.; Fauci, A.S. Immune correlates of vaccine protection against HIV-1 acquisition. Sci. Transl. Med. 2015, 7, 310rv7. [CrossRef]

9. Tomaras, G.D.; Plotkin, S.A. Complex immune correlates of protection in HIV-1 vaccine efficacy trials. Immunol. Rev. 2017, 275, 245-261. [CrossRef]

10. Liang, B.; Li, H.; Li, L.; Omange, R.W.; Hai, Y.; Luo, M. Current advances in HIV vaccine preclinical studies using Macaque models. Vaccine 2019, 37, 3388-3399. [CrossRef]

11. Rahman, M.A.; Robert-Guroff, M. Accelerating HIV vaccine development using non-human primate models. Expert Rev. Vaccines 2019, 18, 61-73. [CrossRef]

12. Manickam, C.; Shah, S.V.; Nohara, J.; Ferrari, G.; Reeves, R.K. Monkeying Around: Using Non-human Primate Models to Study NK Cell Biology in HIV Infections. Front. Immunol. 2019, 10, 1124. [CrossRef] [PubMed]

13. Chen, Z. Monkey Models and HIV Vaccine Research. In HIV Vaccines and Cure; Advances in Experimental Medicine and Biology; Zhang, L., Lewin, S., Eds.; Springer: Singapore, 2018; Volume 1075, pp. 97-124.

14. Rogers, J.; Gibbs, R.A. Comparative primate genomics: Emerging patterns of genome content and dynamics. Nat. Rev. Genet. 2014, 15, 347-359. [CrossRef] [PubMed]

15. Boesch, A.W.; Osei-Owusu, N.Y.; Crowley, A.R.; Chu, T.H.; Chan, Y.N.; Weiner, J.A.; Bharadwaj, P.; Hards, R.; Adamo, M.E.; Gerber, S.A.; et al. Biophysical and Functional Characterization of Rhesus Macaque IgG Subclasses. Front. Immunol. 2016, 7, 589. [CrossRef] [PubMed]

16. Rogers, K.A.; Jayashankar, L.; Scinicariello, F.; Attanasio, R. Nonhuman primate IgA: Genetic heterogeneity and interactions with CD89. J. Immunol. 2008, 180, 4816-4824. [CrossRef] [PubMed]

17. Thullier, P.; Chahboun, S.; Pelat, T. A comparison of human and macaque (Macaca mulatta) immunoglobulin germline $\mathrm{V}$ regions and its implications for antibody engineering. $m A b s$ 2010, 2, 528-538. [CrossRef] [PubMed]

18. Thullier, P.; Huish, O.; Pelat, T.; Martin, A.C. The humanness of macaque antibody sequences. J. Mol. Biol. 2010, 396, 1439-1450. [CrossRef] 
19. Liu, L.; Li, L.; Nanfack, A.; Mayr, L.M.; Soni, S.; Kohutnicki, A.; Agyingi, L.; Wang, X.H.; Tuen, M.; Shao, Y.; et al. Anti-V2 antibody deficiency in individuals infected with HIV-1 in Cameroon. Virology 2019, 529, 57-64. [CrossRef]

20. Tuen, M.; Bimela, J.S.; Banin, A.N.; Ding, S.; Harkins, G.W.; Weiss, S.; Itri, V.; Durham, A.R.; Porcella, S.F.; Soni, S.; et al. Immune Correlates of Disease Progression in Linked HIV-1 Infection. Front. Immunol. 2019, 10, 1062. [CrossRef]

21. Van Eeden, C.; Wibmer, C.K.; Scheepers, C.; Richardson, S.I.; Nonyane, M.; Lambson, B.; Mkhize, N.N.; Vijayakumar, B.; Sheng, Z.; Stanfield-Oakley, S.; et al. V2-Directed Vaccine-like Antibodies from HIV-1 Infection Identify an Additional K169-Binding Light Chain Motif with Broad ADCC Activity. Cell Rep. 2018, 25, 3123-3135. [CrossRef]

22. Wibmer, C.K.; Richardson, S.I.; Yolitz, J.; Cicala, C.; Arthos, J.; Moore, P.L.; Morris, L. Common helical V1V2 conformations of HIV-1 Envelope expose the alpha4beta7 binding site on intact virions. Nat. Commun. 2018, 9, 4489. [CrossRef]

23. Mayr, L.M.; Cohen, S.; Spurrier, B.; Kong, X.P.; Zolla-Pazner, S. Epitope mapping of conformational V2-specific anti-HIV human monoclonal antibodies reveals an immunodominant site in V2. PLoS ONE 2013, 8, e70859. [CrossRef] [PubMed]

24. Zolla-Pazner, S.; Alvarez, R.; Kong, X.P.; Weiss, S. Vaccine-induced V1V2-specific antibodies control and or protect against infection with HIV, SIV and SHIV. Curr. Opin. HIV AIDS 2019, 14, 309-317. [CrossRef] [PubMed]

25. Shen, G.; Upadhyay, C.; Zhang, J.; Pan, R.; Zolla-Pazner, S.; Kong, X.P.; Hioe, C.E. Rationally Targeted Mutations at the V1V2 Domain of the HIV-1 Envelope to Augment Virus Neutralization by Anti-V1V2 Monoclonal Antibodies. PLoS ONE 2015, 10, e0141233. [CrossRef] [PubMed]

26. Spurrier, B.; Sampson, J.; Gorny, M.K.; Zolla-Pazner, S.; Kong, X.P. Functional implications of the binding mode of a human conformation-dependent V2 monoclonal antibody against HIV. J. Virol. 2014, 88, 4100-4112. [CrossRef] [PubMed]

27. Upadhyay, C.; Mayr, L.M.; Zhang, J.; Kumar, R.; Gorny, M.K.; Nadas, A.; Zolla-Pazner, S.; Hioe, C.E. Distinct mechanisms regulate exposure of neutralizing epitopes in the V2 and V3 loops of HIV-1 envelope. J. Virol. 2014, 88, 12853-12865. [CrossRef] [PubMed]

28. Jan, M.; Upadhyay, C.; Sharma, A.; Hioe, C.E.; Arora, S.K. Short Communication: Manalpha1-2Man-Binding Anti-HIV Lectins Enhance the Exposure of V2i and V3 Crown Neutralization Epitopes on the V1/V2 and V3 Hypervariable Loops of HIV-1 Envelope. AIDS Res. Hum. Retrovir. 2017, 33, 941-945. [CrossRef] [PubMed]

29. Doria-Rose, N.A.; Schramm, C.A.; Gorman, J.; Moore, P.L.; Bhiman, J.N.; DeKosky, B.J.; Ernandes, M.J.; Georgiev, I.S.; Kim, H.J.; Pancera, M.; et al. Developmental pathway for potent V1V2-directed HIV-neutralizing antibodies. Nature 2014, 509, 55-62. [CrossRef] [PubMed]

30. Landais, E.; Huang, X.; Havenar-Daughton, C.; Murrell, B.; Price, M.A.; Wickramasinghe, L.; Ramos, A.; Bian, C.B.; Simek, M.; Allen, S.; et al. Broadly Neutralizing Antibody Responses in a Large Longitudinal Sub-Saharan HIV Primary Infection Cohort. PLoS Pathog. 2016, 12, e1005369. [CrossRef] [PubMed]

31. Liao, H.X.; Bonsignori, M.; Alam, S.M.; McLellan, J.S.; Tomaras, G.D.; Moody, M.A.; Kozink, D.M.; Hwang, K.K.; Chen, X.; Tsao, C.Y.; et al. Vaccine induction of antibodies against a structurally heterogeneous site of immune pressure within HIV-1 envelope protein variable regions 1 and 2. Immunity 2013, 38, 176-186. [CrossRef]

32. Walker, L.M.; Phogat, S.K.; Chan-Hui, P.Y.; Wagner, D.; Phung, P.; Goss, J.L.; Wrin, T.; Simek, M.D.; Fling, S.; Mitcham, J.L.; et al. Broad and potent neutralizing antibodies from an African donor reveal a new HIV-1 vaccine target. Science 2009, 326, 285-289. [CrossRef]

33. Walker, L.M.; Huber, M.; Doores, K.J.; Falkowska, E.; Pejchal, R.; Julien, J.P.; Wang, S.K.; Ramos, A.; Chan-Hui, P.Y.; Moyle, M.; et al. Broad neutralization coverage of HIV by multiple highly potent antibodies. Nature 2011, 477, 466-470. [CrossRef] [PubMed]

34. Gorny, M.K.; Moore, J.P.; Conley, A.J.; Karwowska, S.; Sodroski, J.; Williams, C.; Burda, S.; Boots, L.J.; Zolla-Pazner, S. Human anti-V2 monoclonal antibody that neutralizes primary but not laboratory isolates of human immunodeficiency virus type 1. J. Virol. 1994, 68, 8312-8320. [PubMed]

35. Gorny, M.K.; Pan, R.; Williams, C.; Wang, X.H.; Volsky, B.; O’Neal, T.; Spurrier, B.; Sampson, J.M.; Li, L.; Seaman, M.S.; et al. Functional and immunochemical cross-reactivity of V2-specific monoclonal antibodies from HIV-1-infected individuals. Virology 2012, 427, 198-207. [CrossRef] [PubMed] 
36. Nyambi, P.N.; Mbah, H.A.; Burda, S.; Williams, C.; Gorny, M.K.; Nadas, A.; Zolla-Pazner, S. Conserved and exposed epitopes on intact, native, primary human immunodeficiency virus type 1 virions of group M. J. Virol. 2000, 74, 7096-7107. [CrossRef] [PubMed]

37. Pinter, A.; Honnen, W.J.; He, Y.; Gorny, M.K.; Zolla-Pazner, S.; Kayman, S.C. The V1/V2 domain of gp120 is a global regulator of the sensitivity of primary human immunodeficiency virus type 1 isolates to neutralization by antibodies commonly induced upon infection. J. Virol. 2004, 78, 5205-5215. [CrossRef] [PubMed]

38. Andrabi, R.; Pallesen, J.; Allen, J.D.; Song, G.; Zhang, J.; de Val, N.; Gegg, G.; Porter, K.; Su, C.Y.; Pauthner, M.; et al. The Chimpanzee SIV Envelope Trimer: Structure and Deployment as an HIV Vaccine Template. Cell Rep. 2019, 27, 2426-2441.e6. [CrossRef] [PubMed]

39. Stamatatos, L.; Pancera, M.; McGuire, A.T. Germline-targeting immunogens. Immunol. Rev. 2017, 275, 203-216. [CrossRef] [PubMed]

40. Morris, L.; Mkhize, N.N. Prospects for passive immunity to prevent HIV infection. PLoS Med. 2017, 14, e1002436. [CrossRef]

41. O'Connell, R.J.; Kim, J.H.; Excler, J.L. The HIV-1 gp120 V1V2 loop: Structure, function and importance for vaccine development. Expert Rev. Vaccines 2014, 13, 1489-1500. [CrossRef]

42. Totrov, M. Estimated secondary structure propensities within V1/V2 region of HIV gp120 are an important global antibody neutralization sensitivity determinant. PLoS ONE 2014, 9, e94002. [CrossRef]

43. Ward, A.B.; Wilson, I.A. The HIV-1 envelope glycoprotein structure: Nailing down a moving target. Immunol. Rev. 2017, 275, 21-32. [CrossRef] [PubMed]

44. Andrabi, R.; Voss, J.E.; Liang, C.H.; Briney, B.; McCoy, L.E.; Wu, C.Y.; Wong, C.H.; Poignard, P.; Burton, D.R. Identification of Common Features in Prototype Broadly Neutralizing Antibodies to HIV Envelope V2 Apex to Facilitate Vaccine Design. Immunity 2015, 43, 959-973. [CrossRef]

45. Wang, H.; Gristick, H.B.; Scharf, L.; West, A.P.; Galimidi, R.P.; Seaman, M.S.; Freund, N.T.; Nussenzweig, M.C.; Bjorkman, P.J. Asymmetric recognition of HIV-1 Envelope trimer by V1V2 loop-targeting antibodies. eLife 2017, 6, e27389. [CrossRef] [PubMed]

46. Lyumkis, D.; Julien, J.P.; de Val, N.; Cupo, A.; Potter, C.S.; Klasse, P.J.; Burton, D.R.; Sanders, R.W.; Moore, J.P.; Carragher, B.; et al. Cryo-EM structure of a fully glycosylated soluble cleaved HIV-1 envelope trimer. Science 2013, 342, 1484-1490. [CrossRef] [PubMed]

47. Pan, R.; Gorny, M.K.; Zolla-Pazner, S.; Kong, X.P. The V1V2 Region of HIV-1 gp120 Forms a Five-Stranded Beta Barrel. J. Virol. 2015, 89, 8003-8010. [CrossRef] [PubMed]

48. Liu, J.; Bartesaghi, A.; Borgnia, M.J.; Sapiro, G.; Subramaniam, S. Molecular architecture of native HIV-1 gp120 trimers. Nature 2008, 455, 109-113. [CrossRef] [PubMed]

49. Jiang, X.; Totrov, M.; Li, W.; Sampson, J.M.; Williams, C.; Lu, H.; Wu, X.; Lu, S.; Wang, S.; Zolla-Pazner, S.; et al. Rationally Designed Immunogens Targeting HIV-1 gp120 V1V2 Induce Distinct Conformation-Specific Antibody Responses in Rabbits. J. Virol. 2016, 90, 11007-11019. [CrossRef]

50. Zolla-Pazner, S.; deCamp, A.; Gilbert, P.B.; Williams, C.; Yates, N.L.; Williams, W.T.; Howington, R.; Fong, Y.; Morris, D.E.; Soderberg, K.A.; et al. Vaccine-induced IgG antibodies to V1V2 regions of multiple HIV-1 subtypes correlate with decreased risk of HIV-1 infection. PLoS ONE 2014, 9, e87572. [CrossRef]

51. Gottardo, R.; Bailer, R.T.; Korber, B.T.; Gnanakaran, S.; Phillips, J.; Shen, X.; Tomaras, G.D.; Turk, E.; Imholte, G.; Eckler, L.; et al. Plasma IgG to linear epitopes in the V2 and V3 regions of HIV-1 gp120 correlate with a reduced risk of infection in the RV144 vaccine efficacy trial. PLoS ONE 2013, 8, e75665. [CrossRef]

52. Ozorowski, G.; Pallesen, J.; de Val, N.; Lyumkis, D.; Cottrell, C.A.; Torres, J.L.; Copps, J.; Stanfield, R.L.; Cupo, A.; Pugach, P.; et al. Open and closed structures reveal allostery and pliability in the HIV-1 envelope spike. Nature 2017, 547, 360-363. [CrossRef]

53. Gorman, J.; Soto, C.; Yang, M.M.; Davenport, T.M.; Guttman, M.; Bailer, R.T.; Chambers, M.; Chuang, G.Y.; DeKosky, B.J.; Doria-Rose, N.A.; et al. Structures of HIV-1 Env V1V2 with broadly neutralizing antibodies reveal commonalities that enable vaccine design. Nat. Struct. Mol. Biol. 2016, 23, 81-90. [CrossRef] [PubMed]

54. Lee, J.H.; Andrabi, R.; Su, C.Y.; Yasmeen, A.; Julien, J.P.; Kong, L.; Wu, N.C.; McBride, R.; Sok, D.; Pauthner, M.; et al. A Broadly Neutralizing Antibody Targets the Dynamic HIV Envelope Trimer Apex via a Long, Rigidified, and Anionic beta-Hairpin Structure. Immunity 2017, 46, 690-702. [CrossRef] [PubMed]

55. McBurney, S.P.; Ross, T.M. Viral sequence diversity: Challenges for AIDS vaccine designs. Expert Rev. Vaccines 2008, 7, 1405-1417. [CrossRef] [PubMed] 
56. Stefic, K.; Bouvin-Pley, M.; Braibant, M.; Barin, F. Impact of HIV-1 Diversity on Its Sensitivity to Neutralization. Vaccines 2019, 7, 74. [CrossRef] [PubMed]

57. Stewart-Jones, G.B.; Soto, C.; Lemmin, T.; Chuang, G.Y.; Druz, A.; Kong, R.; Thomas, P.V.; Wagh, K.; Zhou, T.; Behrens, A.J.; et al. Trimeric HIV-1-Env Structures Define Glycan Shields from Clades A, B, and G. Cell 2016, 165, 813-826. [CrossRef] [PubMed]

58. Julien, J.P.; Lee, J.H.; Ozorowski, G.; Hua, Y.; Torrents de la Pena, A.; de Taeye, S.W.; Nieusma, T.; Cupo, A.; Yasmeen, A.; Golabek, M.; et al. Design and structure of two HIV-1 clade C SOSIP.664 trimers that increase the arsenal of native-like Env immunogens. Proc. Natl. Acad. Sci. USA 2015, 112, 11947-11952. [CrossRef] [PubMed]

59. Israel, Z.R.; Gorny, M.K.; Palmer, C.; McKeating, J.A.; Zolla-Pazner, S. Prevalence of a V2 epitope in clade B primary isolates and its recognition by sera from HIV-1-infected individuals. AIDS 1997, 11, 128-130.

60. Kayman, S.C.; Wu, Z.; Revesz, K.; Chen, H.; Kopelman, R.; Pinter, A. Presentation of native epitopes in the V1/V2 and V3 regions of human immunodeficiency virus type 1 gp120 by fusion glycoproteins containing isolated gp120 domains. J. Virol. 1994, 68, 400-410.

61. McKeating, J.A.; Shotton, C.; Cordell, J.; Graham, S.; Balfe, P.; Sullivan, N.; Charles, M.; Page, M.; Bolmstedt, A.; Olofsson, S.; et al. Characterization of neutralizing monoclonal antibodies to linear and conformation-dependent epitopes within the first and second variable domains of human immunodeficiency virus type 1 gp120. J. Virol. 1993, 67, 4932-4944.

62. Moore, J.P.; Sattentau, Q.J.; Yoshiyama, H.; Thali, M.; Charles, M.; Sullivan, N.; Poon, S.W.; Fung, M.S.; Traincard, F.; Pinkus, M.; et al. Probing the structure of the V2 domain of human immunodeficiency virus type 1 surface glycoprotein gp120 with a panel of eight monoclonal antibodies: Human immune response to the V1 and V2 domains. J. Virol. 1993, 67, 6136-6151.

63. Karasavvas, N.; Billings, E.; Rao, M.; Williams, C.; Zolla-Pazner, S.; Bailer, R.T.; Koup, R.A.; Madnote, S.; Arworn, D.; Shen, X.; et al. The Thai Phase III HIV Type 1 Vaccine trial (RV144) regimen induces antibodies that target conserved regions within the V2 loop of gp120. AIDS Res. Hum. Retrovir. 2012, 28, 1444-1457. [CrossRef] [PubMed]

64. Hioe, C.E.; Kumar, R.; Upadhyay, C.; Jan, M.; Fox, A.; Itri, V.; Peachman, K.K.; Rao, M.; Liu, L.; Lo, N.C.; et al. Modulation of Antibody Responses to the V1V2 and V3 Regions of HIV-1 Envelope by Immune Complex Vaccines. Front. Immunol. 2018, 9, 2441. [CrossRef] [PubMed]

65. Hessell, A.J.; Powell, R.; Jiang, X.; Luo, C.; Weiss, S.; Dussupt, V.; Itri, V.; Fox, A.; Shapiro, M.B.; Pandey, S.; et al. Multimeric Epitope-Scaffold HIV Vaccines Target V1V2 and Differentially Tune Polyfunctional Antibody Responses. Cell Rep. 2019, 28, 877-895. [CrossRef] [PubMed]

66. Jones, A.T.; Chamcha, V.; Kesavardhana, S.; Shen, X.; Beaumont, D.; Das, R.; Wyatt, L.S.; LaBranche, C.C.; Stanfield-Oakley, S.; Ferrari, G.; et al. A Trimeric HIV-1 Envelope gp120 Immunogen Induces Potent and Broad Anti-V1V2 Loop Antibodies against HIV-1 in Rabbits and Rhesus Macaques. J. Virol. $2018,92$. [CrossRef] [PubMed]

67. Karch, C.P.; Bai, H.; Torres, O.B.; Tucker, C.A.; Michael, N.L.; Matyas, G.R.; Rolland, M.; Burkhard, P.; Beck, Z. Design and characterization of a self-assembling protein nanoparticle displaying HIV-1 Env V1V2 loop in a native-like trimeric conformation as vaccine antigen. Nanomedicine 2019, 16, 206-216. [CrossRef] [PubMed]

68. Lai, J.I.; Verma, D.; Bailey-Kellogg, C.; Ackerman, M.E. Towards conformational fidelity of a quaternary HIV-1 epitope: Computational design and directed evolution of a minimal V1V2 antigen. Protein Eng. Des. Sel. 2018, 31, 121-133. [CrossRef] [PubMed]

69. Shen, X.; Duffy, R.; Howington, R.; Cope, A.; Sadagopal, S.; Park, H.; Pal, R.; Kwa, S.; Ding, S.; Yang, O.O.; et al. Vaccine-Induced Linear Epitope-Specific Antibodies to Simian Immunodeficiency Virus SIVmac239 Envelope Are Distinct from Those Induced to the Human Immunodeficiency Virus Type 1 Envelope in Nonhuman Primates. J. Virol. 2015, 89, 8643-8650. [CrossRef] [PubMed]

70. Bowder, D.; Thompson, J.; Durst, K.; Hollingsead, H.; Hu, D.Y.; Wei, W.Z.; Xiang, S.H. Characterization of twin-cysteine motif in the V2-loop region of gp120 in primate lentiviruses. Virology 2018, 519, 180-189. [CrossRef]

71. Cicala, C.; Arthos, J.; Selig, S.M.; Dennis, G., Jr.; Hosack, D.A.; Van Ryk, D.; Spangler, M.L.; Steenbeke, T.D.; Khazanie, P.; Gupta, N.; et al. HIV envelope induces a cascade of cell signals in non-proliferating target cells that favor virus replication. Proc. Natl. Acad. Sci. USA 2002, 99, 9380-9385. [CrossRef] 
72. Guerra, S.; Gonzalez, J.M.; Climent, N.; Reyburn, H.; Lopez-Fernandez, L.A.; Najera, J.L.; Gomez, C.E.; Garcia, F.; Gatell, J.M.; Gallart, T.; et al. Selective induction of host genes by MVA-B, a candidate vaccine against HIV/AIDS. J. Virol. 2010, 84, 8141-8152. [CrossRef]

73. Vaccari, M.; Gordon, S.N.; Fourati, S.; Schifanella, L.; Liyanage, N.P.; Cameron, M.; Keele, B.F.; Shen, X.; Tomaras, G.D.; Billings, E.; et al. Adjuvant-dependent innate and adaptive immune signatures of risk of SIVmac251 acquisition. Nat. Med. 2016, 22, 762-770. [CrossRef] [PubMed]

74. Cao, L.; Diedrich, J.K.; Kulp, D.W.; Pauthner, M.; He, L.; Park, S.R.; Sok, D.; Su, C.Y.; Delahunty, C.M.; Menis, S.; et al. Global site-specific N-glycosylation analysis of HIV envelope glycoprotein. Nat. Commun. 2017, 8, 14954. [CrossRef] [PubMed]

75. Cole, K.S.; Steckbeck, J.D.; Rowles, J.L.; Desrosiers, R.C.; Montelaro, R.C. Removal of N-linked glycosylation sites in the V1 region of simian immunodeficiency virus gp120 results in redirection of B-cell responses to V3. J. Virol. 2004, 78, 1525-1539. [CrossRef] [PubMed]

76. Yen, P.J.; Herschhorn, A.; Haim, H.; Salas, I.; Gu, C.; Sodroski, J.; Gabuzda, D. Loss of a conserved $\mathrm{N}$-linked glycosylation site in the simian immunodeficiency virus envelope glycoprotein $\mathrm{V} 2$ region enhances macrophage tropism by increasing CD4-independent cell-to-cell transmission. J. Virol. 2014, 88, 5014-5028. [CrossRef] [PubMed]

77. Balazs, A.B.; Ouyang, Y.; Hong, C.M.; Chen, J.; Nguyen, S.M.; Rao, D.S.; An, D.S.; Baltimore, D. Vectored immunoprophylaxis protects humanized mice from mucosal HIV transmission. Nat. Med. 2014, 20, $296-300$. [CrossRef] [PubMed]

78. Hessell, A.J.; Jaworski, J.P.; Epson, E.; Matsuda, K.; Pandey, S.; Kahl, C.; Reed, J.; Sutton, W.F.; Hammond, K.B.; Cheever, T.A.; et al. Early short-term treatment with neutralizing human monoclonal antibodies halts SHIV infection in infant macaques. Nat. Med. 2016, 22, 362-368. [CrossRef] [PubMed]

79. Montefiori, D.C.; Karnasuta, C.; Huang, Y.; Ahmed, H.; Gilbert, P.; de Souza, M.S.; McLinden, R.; Tovanabutra, S.; Laurence-Chenine, A.; Sanders-Buell, E.; et al. Magnitude and breadth of the neutralizing antibody response in the RV144 and Vax003 HIV-1 vaccine efficacy trials. J. Infect. Dis. 2012, 206, 431-441. [CrossRef]

80. Corti, D.; Langedijk, J.P.; Hinz, A.; Seaman, M.S.; Vanzetta, F.; Fernandez-Rodriguez, B.M.; Silacci, C.; Pinna, D.; Jarrossay, D.; Balla-Jhaghhoorsingh, S.; et al. Analysis of memory B cell responses and isolation of novel monoclonal antibodies with neutralizing breadth from HIV-1-infected individuals. PLoS ONE 2010, 5, e8805. [CrossRef]

81. Li, L.; Wang, X.H.; Williams, C.; Volsky, B.; Steczko, O.; Seaman, M.S.; Luthra, K.; Nyambi, P.; Nadas, A.; Giudicelli, V.; et al. A broad range of mutations in HIV-1 neutralizing human monoclonal antibodies specific for V2, V3, and the CD4 binding site. Mol. Immunol. 2015, 66, 364-374. [CrossRef]

82. Excler, J.L.; Ake, J.; Robb, M.L.; Kim, J.H.; Plotkin, S.A. Nonneutralizing functional antibodies: A new "old" paradigm for HIV vaccines. Clin. Vaccine Immunol. 2014, 21, 1023-1036. [CrossRef]

83. Burton, D.R.; Mascola, J.R. Antibody responses to envelope glycoproteins in HIV-1 infection. Nat. Immunol. 2015, 16, 571-576. [CrossRef] [PubMed]

84. McCoy, L.E.; Burton, D.R. Identification and specificity of broadly neutralizing antibodies against HIV. Immunol. Rev. 2017, 275, 11-20. [CrossRef] [PubMed]

85. Bai, H.; Li, Y.; Michael, N.L.; Robb, M.L.; Rolland, M. The breadth of HIV-1 neutralizing antibodies depends on the conservation of key sites in their epitopes. PLoS Comput. Biol. 2019, 15, e1007056. [CrossRef] [PubMed]

86. Burton, D.R.; Hangartner, L. Broadly Neutralizing Antibodies to HIV and Their Role in Vaccine Design. Annu. Rev. Immunol. 2016, 34, 635-659. [CrossRef] [PubMed]

87. Caskey, M.; Klein, F.; Nussenzweig, M.C. Broadly neutralizing anti-HIV-1 monoclonal antibodies in the clinic. Nat. Med. 2019, 25, 547-553. [CrossRef] [PubMed]

88. McCoy, L.E. The expanding array of HIV broadly neutralizing antibodies. Retrovirology 2018, 15, 70. [CrossRef]

89. Georgiev, I.S.; Doria-Rose, N.A.; Zhou, T.; Kwon, Y.D.; Staupe, R.P.; Moquin, S.; Chuang, G.Y.; Louder, M.K.; Schmidt, S.D.; Altae-Tran, H.R.; et al. Delineating antibody recognition in polyclonal sera from patterns of HIV-1 isolate neutralization. Science 2013, 340, 751-756. [CrossRef]

90. Sok, D.; van Gils, M.J.; Pauthner, M.; Julien, J.P.; Saye-Francisco, K.L.; Hsueh, J.; Briney, B.; Lee, J.H.; Le, K.M.; Lee, P.S.; et al. Recombinant HIV envelope trimer selects for quaternary-dependent antibodies targeting the trimer apex. Proc. Natl. Acad. Sci. USA 2014, 111, 17624-17629. [CrossRef] 
91. Bonsignori, M.; Hwang, K.K.; Chen, X.; Tsao, C.Y.; Morris, L.; Gray, E.; Marshall, D.J.; Crump, J.A.; Kapiga, S.H.; Sam, N.E.; et al. Analysis of a clonal lineage of HIV-1 envelope V2/V3 conformational epitope-specific broadly neutralizing antibodies and their inferred unmutated common ancestors. J. Virol. 2011, 85, 9998-10009. [CrossRef]

92. Doria-Rose, N.A.; Bhiman, J.N.; Roark, R.S.; Schramm, C.A.; Gorman, J.; Chuang, G.Y.; Pancera, M.; Cale, E.M.; Ernandes, M.J.; Louder, M.K.; et al. New Member of the V1V2-Directed CAP256-VRC26 Lineage That Shows Increased Breadth and Exceptional Potency. J. Virol. 2016, 90, 76-91. [CrossRef]

93. Cale, E.M.; Gorman, J.; Radakovich, N.A.; Crooks, E.T.; Osawa, K.; Tong, T.; Li, J.; Nagarajan, R.; Ozorowski, G.; Ambrozak, D.R.; et al. Virus-like Particles Identify an HIV V1V2 Apex-Binding Neutralizing Antibody that Lacks a Protruding Loop. Immunity 2017, 46, 777-791. [CrossRef]

94. Andrabi, R.; Su, C.Y.; Liang, C.H.; Shivatare, S.S.; Briney, B.; Voss, J.E.; Nawazi, S.K.; Wu, C.Y.; Wong, C.H.; Burton, D.R. Glycans Function as Anchors for Antibodies and Help Drive HIV Broadly Neutralizing Antibody Development. Immunity 2017, 47, 524-537. [CrossRef]

95. Landais, E.; Murrell, B.; Briney, B.; Murrell, S.; Rantalainen, K.; Berndsen, Z.T.; Ramos, A.; Wickramasinghe, L.; Smith, M.L.; Eren, K.; et al. HIV Envelope Glycoform Heterogeneity and Localized Diversity Govern the Initiation and Maturation of a V2 Apex Broadly Neutralizing Antibody Lineage. Immunity 2017, 47, 990-1003. [CrossRef]

96. McCoy, L.E.; Falkowska, E.; Doores, K.J.; Le, K.; Sok, D.; van Gils, M.J.; Euler, Z.; Burger, J.A.; Seaman, M.S.; Sanders, R.W.; et al. Incomplete Neutralization and Deviation from Sigmoidal Neutralization Curves for HIV Broadly Neutralizing Monoclonal Antibodies. PLoS Pathog. 2015, 11, e1005110. [CrossRef]

97. Doores, K.J.; Burton, D.R. Variable loop glycan dependency of the broad and potent HIV-1-neutralizing antibodies PG9 and PG16. J. Virol. 2010, 84, 10510-10521. [CrossRef]

98. De Taeye, S.W.; Go, E.P.; Sliepen, K.; de la Pena, A.T.; Badal, K.; Medina-Ramirez, M.; Lee, W.H.; Desaire, H.; Wilson, I.A.; Moore, J.P.; et al. Stabilization of the V2 loop improves the presentation of V2 loop-associated broadly neutralizing antibody epitopes on HIV-1 envelope trimers. J. Biol. Chem. 2019, 294, 5616-5631. [CrossRef]

99. Sliepen, K.; Han, B.W.; Bontjer, I.; Mooij, P.; Garces, F.; Behrens, A.J.; Rantalainen, K.; Kumar, S.; Sarkar, A.; Brouwer, P.J.M.; et al. Structure and immunogenicity of a stabilized HIV-1 envelope trimer based on a group-M consensus sequence. Nat. Commun. 2019, 10, 2355. [CrossRef]

100. Torrents de la Pena, A.; Sanders, R.W. Stabilizing HIV-1 envelope glycoprotein trimers to induce neutralizing antibodies. Retrovirology 2018, 15, 63. [CrossRef]

101. Barouch, D.H.; Stephenson, K.E.; Borducchi, E.N.; Smith, K.; Stanley, K.; McNally, A.G.; Liu, J.; Abbink, P.; Maxfield, L.F.; Seaman, M.S.; et al. Protective efficacy of a global HIV-1 mosaic vaccine against heterologous SHIV challenges in rhesus monkeys. Cell 2013, 155, 531-539. [CrossRef]

102. Musich, T.; Li, L.; Liu, L.; Zolla-Pazner, S.; Robert-Guroff, M.; Gorny, M.K. Monoclonal Antibodies Specific for the V2, V3, CD4-Binding Site, and gp41 of HIV-1 Mediate Phagocytosis in a Dose-Dependent Manner. J. Virol. 2017, 91. [CrossRef]

103. Chung, A.W.; Crispin, M.; Pritchard, L.; Robinson, H.; Gorny, M.K.; Yu, X.; Bailey-Kellogg, C.; Ackerman, M.E.; Scanlan, C.; Zolla-Pazner, S.; et al. Identification of antibody glycosylation structures that predict monoclonal antibody Fc-effector function. AIDS 2014, 28, 2523-2530. [CrossRef]

104. Gach, J.S.; Bouzin, M.; Wong, M.P.; Chromikova, V.; Gorlani, A.; Yu, K.T.; Sharma, B.; Gratton, E.; Forthal, D.N. Human immunodeficiency virus type-1 (HIV-1) evades antibody-dependent phagocytosis. PLoS Pathog. 2017, 13, e1006793. [CrossRef]

105. Bradley, T.; Pollara, J.; Santra, S.; Vandergrift, N.; Pittala, S.; Bailey-Kellogg, C.; Shen, X.; Parks, R.; Goodman, D.; Eaton, A.; et al. Pentavalent HIV-1 vaccine protects against simian-human immunodeficiency virus challenge. Nat. Commun. 2017, 8, 15711. [CrossRef]

106. Mayr, L.M.; Decoville, T.; Schmidt, S.; Laumond, G.; Klingler, J.; Ducloy, C.; Bahram, S.; Zolla-Pazner, S.; Moog, C. Non-neutralizing Antibodies Targeting the V1V2 Domain of HIV Exhibit Strong Antibody-Dependent Cell-mediated Cytotoxic Activity. Sci. Rep. 2017, 7, 12655. [CrossRef]

107. Forthal, D.N.; Finzi, A. Antibody-dependent cellular cytotoxicity in HIV infection. AIDS 2018, 32, $2439-2451$. [CrossRef] 
108. Zolla-Pazner, S.; deCamp, A.C.; Cardozo, T.; Karasavvas, N.; Gottardo, R.; Williams, C.; Morris, D.E.; Tomaras, G.; Rao, M.; Billings, E.; et al. Analysis of V2 antibody responses induced in vaccinees in the ALVAC/AIDSVAX HIV-1 vaccine efficacy trial. PLoS ONE 2013, 8, e53629. [CrossRef]

109. Wiehe, K.; Easterhoff, D.; Luo, K.; Nicely, N.I.; Bradley, T.; Jaeger, F.H.; Dennison, S.M.; Zhang, R.; Lloyd, K.E.; Stolarchuk, C.; et al. Antibody light-chain-restricted recognition of the site of immune pressure in the RV144 HIV-1 vaccine trial is phylogenetically conserved. Immunity 2014, 41, 909-918. [CrossRef]

110. Alter, G.; Barouch, D. Immune Correlate-Guided HIV Vaccine Design. Cell Host Microbe 2018, 24, $25-33$. [CrossRef]

111. Ackerman, M.E.; Mikhailova, A.; Brown, E.P.; Dowell, K.G.; Walker, B.D.; Bailey-Kellogg, C.; Suscovich, T.J.; Alter, G. Polyfunctional HIV-Specific Antibody Responses Are Associated with Spontaneous HIV Control. PLoS Pathog. 2016, 12, e1005315. [CrossRef]

112. Anand, S.P.; Prevost, J.; Baril, S.; Richard, J.; Medjahed, H.; Chapleau, J.P.; Tolbert, W.D.; Kirk, S.; Smith, A.B., 3rd; Wines, B.D.; et al. Two Families of Env Antibodies Efficiently Engage Fc-Gamma Receptors and Eliminate HIV-1-Infected Cells. J. Virol. 2019, 93. [CrossRef]

113. Calenda, G.; Frank, I.; Arrode-Bruses, G.; Pegu, A.; Wang, K.; Arthos, J.; Cicala, C.; Rogers, K.A.; Shirreff, L.; Grasperge, B.; et al. Delayed vaginal SHIV infection in VRC01 and anti-alpha4beta7 treated rhesus macaques. PLoS Pathog. 2019, 15, e1007776. [CrossRef]

114. Pollara, J.; Bonsignori, M.; Moody, M.A.; Liu, P.; Alam, S.M.; Hwang, K.K.; Gurley, T.C.; Kozink, D.M.; Armand, L.C.; Marshall, D.J.; et al. HIV-1 vaccine-induced C1 and V2 Env-specific antibodies synergize for increased antiviral activities. J. Virol. 2014, 88, 7715-7726. [CrossRef]

115. Perez, L.G.; Martinez, D.R.; deCamp, A.C.; Pinter, A.; Berman, P.W.; Francis, D.; Sinangil, F.; Lee, C.; Greene, K.; Gao, H.; et al. V1V2-specific complement activating serum IgG as a correlate of reduced HIV-1 infection risk in RV144. PLoS ONE 2017, 12, e0180720. [CrossRef]

116. Buchbinder, S.P.; Mehrotra, D.V.; Duerr, A.; Fitzgerald, D.W.; Mogg, R.; Li, D.; Gilbert, P.B.; Lama, J.R.; Marmor, M.; Del Rio, C.; et al. Efficacy assessment of a cell-mediated immunity HIV-1 vaccine (the Step Study): A double-blind, randomised, placebo-controlled, test-of-concept trial. Lancet 2008, 372, 1881-1893. [CrossRef]

117. Gray, G.E.; Allen, M.; Moodie, Z.; Churchyard, G.; Bekker, L.G.; Nchabeleng, M.; Mlisana, K.; Metch, B.; de Bruyn, G.; Latka, M.H.; et al. Safety and efficacy of the HVTN 503/Phambili study of a clade-B-based HIV-1 vaccine in South Africa: A double-blind, randomised, placebo-controlled test-of-concept phase $2 b$ study. Lancet Infect. Dis. 2011, 11, 507-515. [CrossRef]

118. Flynn, N.M.; Forthal, D.N.; Harro, C.D.; Judson, F.N.; Mayer, K.H.; Para, M.F.; rgp120 HIV Vaccine Study Group. Placebo-controlled phase 3 trial of a recombinant glycoprotein 120 vaccine to prevent HIV-1 infection. J. Infect. Dis. 2005, 191, 654-665. [CrossRef]

119. Pitisuttithum, P.; Gilbert, P.; Gurwith, M.; Heyward, W.; Martin, M.; van Griensven, F.; Hu, D.; Tappero, J.W.; Choopanya, K.; Bangkok Vaccine Evaluation Group. Randomized, double-blind, placebo-controlled efficacy trial of a bivalent recombinant glycoprotein $120 \mathrm{HIV}-1$ vaccine among injection drug users in Bangkok, Thailand. J. Infect. Dis. 2006, 194, 1661-1671. [CrossRef]

120. Hammer, S.M.; Sobieszczyk, M.E.; Janes, H.; Karuna, S.T.; Mulligan, M.J.; Grove, D.; Koblin, B.A.; Buchbinder, S.P.; Keefer, M.C.; Tomaras, G.D.; et al. Efficacy trial of a DNA/rAd5 HIV-1 preventive vaccine. N. Engl. J. Med. 2013, 369, 2083-2092. [CrossRef]

121. Tomaras, G.D.; Ferrari, G.; Shen, X.; Alam, S.M.; Liao, H.X.; Pollara, J.; Bonsignori, M.; Moody, M.A.; Fong, Y.; Chen, X.; et al. Vaccine-induced plasma IgA specific for the C1 region of the HIV-1 envelope blocks binding and effector function of IgG. Proc. Natl. Acad. Sci. USA 2013, 110, 9019-9024. [CrossRef]

122. Balasubramanian, P.; Williams, C.; Shapiro, M.B.; Sinangil, F.; Higgins, K.; Nadas, A.; Totrov, M.; Kong, X.P.; Fiore-Gartland, A.J.; Haigwood, N.L.; et al. Functional Antibody Response Against V1V2 and V3 of HIV gp120 in the VAX003 and VAX004 Vaccine Trials. Sci. Rep. 2018, 8, 542. [CrossRef]

123. Chung, A.W.; Ghebremichael, M.; Robinson, H.; Brown, E.; Choi, I.; Lane, S.; Dugast, A.S.; Schoen, M.K.; Rolland, M.; Suscovich, T.J.; et al. Polyfunctional Fc-effector profiles mediated by IgG subclass selection distinguish RV144 and VAX003 vaccines. Sci. Transl. Med. 2014, 6, 228ra38. [CrossRef] [PubMed]

124. Karnasuta, C.; Akapirat, S.; Madnote, S.; Savadsuk, H.; Puangkaew, J.; Rittiroongrad, S.; Rerks-Ngarm, S.; Nitayaphan, S.; Pitisuttithum, P.; Kaewkungwal, J.; et al. Comparison of Antibody Responses Induced by 
RV144, VAX003, and VAX004 Vaccination Regimens. AIDS Res. Hum. Retrovir. 2017, 33, 410-423. [CrossRef] [PubMed]

125. Yates, N.L.; Liao, H.X.; Fong, Y.; de Camp, A.; Vandergrift, N.A.; Williams, W.T.; Alam, S.M.; Ferrari, G.; Yang, Z.Y.; Seaton, K.E.; et al. Vaccine-induced Env V1-V2 IgG3 correlates with lower HIV-1 infection risk and declines soon after vaccination. Sci. Transl. Med. 2014, 6, 228ra39. [CrossRef] [PubMed]

126. Kam, Y.W.; Simarmata, D.; Chow, A.; Her, Z.; Teng, T.S.; Ong, E.K.; Renia, L.; Leo, Y.S.; Ng, L.F. Early appearance of neutralizing immunoglobulin G3 antibodies is associated with chikungunya virus clearance and long-term clinical protection. J. Infect. Dis. 2012, 205, 1147-1154. [CrossRef] [PubMed]

127. Roussilhon, C.; Oeuvray, C.; Muller-Graf, C.; Tall, A.; Rogier, C.; Trape, J.F.; Theisen, M.; Balde, A.; Perignon, J.L.; Druilhe, P. Long-term clinical protection from falciparum malaria is strongly associated with IgG3 antibodies to merozoite surface protein 3. PLoS Med. 2007, 4, e320. [CrossRef] [PubMed]

128. Rerks-Ngarm, S.; Pitisuttithum, P.; Excler, J.L.; Nitayaphan, S.; Kaewkungwal, J.; Premsri, N.; Kunasol, P.; Karasavvas, N.; Schuetz, A.; Ngauy, V.; et al. Randomized, Double-Blind Evaluation of Late Boost Strategies for HIV-Uninfected Vaccine Recipients in the RV144 HIV Vaccine Efficacy Trial. J. Infect. Dis. 2017, 215, 1255-1263. [CrossRef] [PubMed]

129. Prevost, J.; Zoubchenok, D.; Richard, J.; Veillette, M.; Pacheco, B.; Coutu, M.; Brassard, N.; Parsons, M.S.; Ruxrungtham, K.; Bunupuradah, T.; et al. Influence of the Envelope gp120 Phe 43 Cavity on HIV-1 Sensitivity to Antibody-Dependent Cell-Mediated Cytotoxicity Responses. J. Virol. 2017, 91, e02452-16. [CrossRef]

130. Alam, S.M.; Liao, H.X.; Tomaras, G.D.; Bonsignori, M.; Tsao, C.Y.; Hwang, K.K.; Chen, H.; Lloyd, K.E.; Bowman, C.; Sutherland, L.; et al. Antigenicity and immunogenicity of RV144 vaccine AIDSVAX clade E envelope immunogen is enhanced by a gp120 N-terminal deletion. J. Virol. 2013, 87, 1554-1568. [CrossRef]

131. Teigler, J.E.; Phogat, S.; Franchini, G.; Hirsch, V.M.; Michael, N.L.; Barouch, D.H. The canarypox virus vector ALVAC induces distinct cytokine responses compared to the vaccinia virus-based vectors MVA and NYVAC in rhesus monkeys. J. Virol. 2014, 88, 1809-1814. [CrossRef]

132. Bonsignori, M.; Pollara, J.; Moody, M.A.; Alpert, M.D.; Chen, X.; Hwang, K.K.; Gilbert, P.B.; Huang, Y.; Gurley, T.C.; Kozink, D.M.; et al. Antibody-dependent cellular cytotoxicity-mediating antibodies from an HIV-1 vaccine efficacy trial target multiple epitopes and preferentially use the VH1 gene family. J. Virol. 2012, 86, 11521-11532. [CrossRef]

133. Hessell, A.J.; Hangartner, L.; Hunter, M.; Havenith, C.E.; Beurskens, F.J.; Bakker, J.M.; Lanigan, C.M.; Landucci, G.; Forthal, D.N.; Parren, P.W.; et al. Fc receptor but not complement binding is important in antibody protection against HIV. Nature 2007, 449, 101-104. [CrossRef] [PubMed]

134. Li, S.S.; Gilbert, P.B.; Tomaras, G.D.; Kijak, G.; Ferrari, G.; Thomas, R.; Pyo, C.W.; Zolla-Pazner, S.; Montefiori, D.; Liao, H.X.; et al. FCGR2C polymorphisms associate with HIV-1 vaccine protection in RV144 trial. J. Clin. Investig. 2014, 124, 3879-3890. [CrossRef] [PubMed]

135. Lassauniere, R.; Tiemessen, C.T. Variability at the FCGR locus: Characterization in Black South Africans and evidence for ethnic variation in and out of Africa. Genes Immun. 2016, 17, 93-104. [CrossRef] [PubMed]

136. Lin, L.; Finak, G.; Ushey, K.; Seshadri, C.; Hawn, T.R.; Frahm, N.; Scriba, T.J.; Mahomed, H.; Hanekom, W.; Bart, P.A.; et al. COMPASS identifies T-cell subsets correlated with clinical outcomes. Nat. Biotechnol. 2015, 33, 610-616. [CrossRef] [PubMed]

137. Barouch, D.H.; Tomaka, F.L.; Wegmann, F.; Stieh, D.J.; Alter, G.; Robb, M.L.; Michael, N.L.; Peter, L.; Nkolola, J.P.; Borducchi, E.N.; et al. Evaluation of a mosaic HIV-1 vaccine in a multicentre, randomised, double-blind, placebo-controlled, phase 1/2a clinical trial (APPROACH) and in rhesus monkeys (NHP 13-19). Lancet 2018, 392, 232-243. [CrossRef]

138. Bekker, L.G.; Moodie, Z.; Grunenberg, N.; Laher, F.; Tomaras, G.D.; Cohen, K.W.; Allen, M.; Malahleha, M.; Mngadi, K.; Daniels, B.; et al. Subtype C ALVAC-HIV and bivalent subtype C gp120/MF59 HIV-1 vaccine in low-risk, HIV-uninfected, South African adults: A phase 1/2 trial. Lancet HIV 2018, 5, e366-e378. [CrossRef]

139. Gray, G.E.; Andersen-Nissen, E.; Grunenberg, N.; Huang, Y.; Roux, S.; Laher, F.; Innes, C.; Gu, N.; DiazGranados, C.; Phogat, S.; et al. HVTN 097: Evaluation of the RV144 Vaccine Regimen in HIV Uninfected South African Adults. AIDS Res. Hum. Retrovir. 2014, 30, A33-A34. [CrossRef]

140. Shen, X.; Moodie, Z.; McMillan, S.; Goodman, D.; Yates, N.L.; Spreng, R.; Grunenberg, N.; Gilbert, P.; Laher, F.; Bekker, L.G.; et al. V1V2 IgG and Antibody Fc Effector Functions in a Subtype C ALVAC-HIV and Bivalent Subtype C gp120/MF59 HIV-1 Vaccine Trial in South Africa. In Proceedings of the HIVR4P 2018, Madrid, Spain, 21-25 October 2018. 
141. Rademeyer, C.; Korber, B.; Seaman, M.S.; Giorgi, E.E.; Thebus, R.; Robles, A.; Sheward, D.J.; Wagh, K.; Garrity, J.; Carey, B.R.; et al. Features of Recently Transmitted HIV-1 Clade C Viruses that Impact Antibody Recognition: Implications for Active and Passive Immunization. PLoS Pathog. 2016, 12, e1005742. [CrossRef]

142. Richardson, S.I.; Gray, E.S.; Mkhize, N.N.; Sheward, D.J.; Lambson, B.E.; Wibmer, C.K.; Masson, L.; Werner, L.; Garrett, N.; Passmore, J.A.; et al. South African HIV-1 subtype C transmitted variants with a specific V2 motif show higher dependence on alpha4beta7 for replication. Retrovirology 2015, 12, 54. [CrossRef]

143. Andrus, L.; Prince, A.M.; Bernal, I.; McCormack, P.; Lee, D.H.; Gorny, M.K.; Zolla-Pazner, S. Passive immunization with a human immunodeficiency virus type 1-neutralizing monoclonal antibody in Hu-PBL-SCID mice: Isolation of a neutralization escape variant. J. Infect. Dis. 1998, 177, 889-897. [CrossRef]

144. Emini, E.A.; Schleif, W.A.; Nunberg, J.H.; Conley, A.J.; Eda, Y.; Tokiyoshi, S.; Putney, S.D.; Matsushita, S.; Cobb, K.E.; Jett, C.M.; et al. Prevention of HIV-1 infection in chimpanzees by gp120 V3 domain-specific monoclonal antibody. Nature 1992, 355, 728-730. [CrossRef] [PubMed]

145. Prince, A.M.; Reesink, H.; Pascual, D.; Horowitz, B.; Hewlett, I.; Murthy, K.K.; Cobb, K.E.; Eichberg, J.W. Prevention of HIV infection by passive immunization with HIV immunoglobulin. AIDS Res. Hum. Retrovir. 1991, 7, 971-973. [CrossRef] [PubMed]

146. Haigwood, N.L.; Montefiori, D.C.; Sutton, W.F.; McClure, J.; Watson, A.J.; Voss, G.; Hirsch, V.M.; Richardson, B.A.; Letvin, N.L.; Hu, S.L.; et al. Passive immunotherapy in simian immunodeficiency virus-infected macaques accelerates the development of neutralizing antibodies. J. Virol. 2004, 78, 5983-5995. [CrossRef] [PubMed]

147. Baba, T.W.; Liska, V.; Hofmann-Lehmann, R.; Vlasak, J.; Xu, W.; Ayehunie, S.; Cavacini, L.A.; Posner, M.R.; Katinger, H.; Stiegler, G.; et al. Human neutralizing monoclonal antibodies of the IgG1 subtype protect against mucosal simian-human immunodeficiency virus infection. Nat. Med. 2000, 6, 200-206. [CrossRef] [PubMed]

148. Mascola, J.R.; Stiegler, G.; VanCott, T.C.; Katinger, H.; Carpenter, C.B.; Hanson, C.E.; Beary, H.; Hayes, D.; Frankel, S.S.; Birx, D.L.; et al. Protection of macaques against vaginal transmission of a pathogenic HIV-1/SIV chimeric virus by passive infusion of neutralizing antibodies. Nat. Med. 2000, 6, 207-210. [CrossRef] [PubMed]

149. Hessell, A.J.; Shapiro, M.B.; Powell, R.; Malherbe, D.C.; McBurney, S.P.; Pandey, S.; Cheever, T.; Sutton, W.F.; Kahl, C.; Park, B.; et al. Reduced Cell-Associated DNA and Improved Viral Control in Macaques following Passive Transfer of a Single Anti-V2 Monoclonal Antibody and Repeated Simian/Human Immunodeficiency Virus Challenges. J. Virol. 2018, 92. [CrossRef] [PubMed]

150. Moog, C.; Dereuddre-Bosquet, N.; Teillaud, J.L.; Biedma, M.E.; Holl, V.; Van Ham, G.; Heyndrickx, L.; Van Dorsselaer, A.; Katinger, D.; Vcelar, B.; et al. Protective effect of vaginal application of neutralizing and nonneutralizing inhibitory antibodies against vaginal SHIV challenge in macaques. Mucosal Immunol. 2014, 7, 46-56. [CrossRef] [PubMed]

151. Burton, D.R.; Hessell, A.J.; Keele, B.F.; Klasse, P.J.; Ketas, T.A.; Moldt, B.; Dunlop, D.C.; Poignard, P.; Doyle, L.A.; Cavacini, L.; et al. Limited or no protection by weakly or nonneutralizing antibodies against vaginal SHIV challenge of macaques compared with a strongly neutralizing antibody. Proc. Natl. Acad. Sci. USA 2011, 108, 11181-11186. [CrossRef] [PubMed]

152. Santra, S.; Tomaras, G.D.; Warrier, R.; Nicely, N.I.; Liao, H.X.; Pollara, J.; Liu, P.; Alam, S.M.; Zhang, R.; Cocklin, S.L.; et al. Human Non-neutralizing HIV-1 Envelope Monoclonal Antibodies Limit the Number of Founder Viruses during SHIV Mucosal Infection in Rhesus Macaques. PLoS Pathog. 2015, 11, e1005042. [CrossRef] [PubMed]

153. Gardner, M.R.; Kattenhorn, L.M.; Kondur, H.R.; von Schaewen, M.; Dorfman, T.; Chiang, J.J.; Haworth, K.G.; Decker, J.M.; Alpert, M.D.; Bailey, C.C.; et al. AAV-expressed eCD4-Ig provides durable protection from multiple SHIV challenges. Nature 2015, 519, 87-91. [CrossRef] [PubMed]

154. Gautam, R.; Nishimura, Y.; Pegu, A.; Nason, M.C.; Klein, F.; Gazumyan, A.; Golijanin, J.; Buckler-White, A.; Sadjadpour, R.; Wang, K.; et al. A single injection of anti-HIV-1 antibodies protects against repeated SHIV challenges. Nature 2016, 533, 105-109. [CrossRef] [PubMed]

155. Hessell, A.J.; Poignard, P.; Hunter, M.; Hangartner, L.; Tehrani, D.M.; Bleeker, W.K.; Parren, P.W.; Marx, P.A.; Burton, D.R. Effective, low-titer antibody protection against low-dose repeated mucosal SHIV challenge in macaques. Nat. Med. 2009, 15, 951-954. [CrossRef] [PubMed] 
156. Hessell, A.J.; Rakasz, E.G.; Poignard, P.; Hangartner, L.; Landucci, G.; Forthal, D.N.; Koff, W.C.; Watkins, D.I.; Burton, D.R. Broadly neutralizing human anti-HIV antibody $2 \mathrm{G} 12$ is effective in protection against mucosal SHIV challenge even at low serum neutralizing titers. PLoS Pathog. 2009, 5, e1000433. [CrossRef] [PubMed]

157. Hessell, A.J.; Rakasz, E.G.; Tehrani, D.M.; Huber, M.; Weisgrau, K.L.; Landucci, G.; Forthal, D.N.; Koff, W.C.; Poignard, P.; Watkins, D.I.; et al. Broadly neutralizing monoclonal antibodies 2F5 and 4E10 directed against the human immunodeficiency virus type 1 gp41 membrane-proximal external region protect against mucosal challenge by simian-human immunodeficiency virus SHIVBa-L. J. Virol. 2010, 84, 1302-1313. [CrossRef] [PubMed]

158. Moldt, B.; Rakasz, E.G.; Schultz, N.; Chan-Hui, P.Y.; Swiderek, K.; Weisgrau, K.L.; Piaskowski, S.M.; Bergman, Z.; Watkins, D.I.; Poignard, P.; et al. Highly potent HIV-specific antibody neutralization in vitro translates into effective protection against mucosal SHIV challenge in vivo. Proc. Natl. Acad. Sci. USA 2012, 109, 18921-18925. [CrossRef] [PubMed]

159. Pegu, A.; Yang, Z.Y.; Boyington, J.C.; Wu, L.; Ko, S.Y.; Schmidt, S.D.; McKee, K.; Kong, W.P.; Shi, W.; Chen, X.; et al. Neutralizing antibodies to HIV-1 envelope protect more effectively in vivo than those to the CD4 receptor. Sci. Transl. Med. 2014, 6, 243ra88. [CrossRef]

160. Shingai, M.; Donau, O.K.; Plishka, R.J.; Buckler-White, A.; Mascola, J.R.; Nabel, G.J.; Nason, M.C.; Montefiori, D.; Moldt, B.; Poignard, P.; et al. Passive transfer of modest titers of potent and broadly neutralizing anti-HIV monoclonal antibodies block SHIV infection in macaques. J. Exp. Med. 2014, 211, 2061-2074. [CrossRef] [PubMed]

161. Xu, L.; Pegu, A.; Rao, E.; Doria-Rose, N.; Beninga, J.; McKee, K.; Lord, D.M.; Wei, R.R.; Deng, G.; Louder, M.; et al. Trispecific broadly neutralizing HIV antibodies mediate potent SHIV protection in macaques. Science 2017, 358, 85-90. [CrossRef]

162. Julg, B.; Tartaglia, L.J.; Keele, B.F.; Wagh, K.; Pegu, A.; Sok, D.; Abbink, P.; Schmidt, S.D.; Wang, K.; Chen, X.; et al. Broadly neutralizing antibodies targeting the HIV-1 envelope V2 apex confer protection against a clade C SHIV challenge. Sci. Transl. Med. 2017, 9. [CrossRef]

163. Pauthner, M.G.; Nkolola, J.P.; Havenar-Daughton, C.; Murrell, B.; Reiss, S.M.; Bastidas, R.; Prevost, J.; Nedellec, R.; von Bredow, B.; Abbink, P.; et al. Vaccine-Induced Protection from Homologous Tier 2 SHIV Challenge in Nonhuman Primates Depends on Serum-Neutralizing Antibody Titers. Immunity 2019, 50, 241-252. [CrossRef]

164. Burton, S.L.; Kilgore, K.M.; Smith, S.A.; Reddy, S.; Hunter, E.; Robinson, H.L.; Silvestri, G.; Amara, R.R.; Derdeyn, C.A. Breakthrough of SIV strain smE660 challenge in SIV strain mac239-vaccinated rhesus macaques despite potent autologous neutralizing antibody responses. Proc. Natl. Acad. Sci. USA 2015, 112, 10780-10785. [CrossRef] [PubMed]

165. Bruel, T.; Guivel-Benhassine, F.; Amraoui, S.; Malbec, M.; Richard, L.; Bourdic, K.; Donahue, D.A.; Lorin, V.; Casartelli, N.; Noel, N.; et al. Elimination of HIV-1-infected cells by broadly neutralizing antibodies. Nat. Commun. 2016, 7, 10844. [CrossRef] [PubMed]

166. Bruel, T.; Guivel-Benhassine, F.; Lorin, V.; Lortat-Jacob, H.; Baleux, F.; Bourdic, K.; Noel, N.; Lambotte, O.; Mouquet, H.; Schwartz, O. Lack of ADCC Breadth of Human Nonneutralizing Anti-HIV-1 Antibodies. J. Virol. 2017, 91, e02440-16. [CrossRef] [PubMed]

167. Ren, Y.; Korom, M.; Truong, R.; Chan, D.; Huang, S.H.; Kovacs, C.C.; Benko, E.; Safrit, J.T.; Lee, J.; Garban, H.; et al. Susceptibility to Neutralization by Broadly Neutralizing Antibodies Generally Correlates with Infected Cell Binding for a Panel of Clade B HIV Reactivated from Latent Reservoirs. J. Virol. 2018, 92, e00895-18. [CrossRef] [PubMed]

168. von Bredow, B.; Arias, J.F.; Heyer, L.N.; Moldt, B.; Le, K.; Robinson, J.E.; Zolla-Pazner, S.; Burton, D.R.; Evans, D.T. Comparison of Antibody-Dependent Cell-Mediated Cytotoxicity and Virus Neutralization by HIV-1 Env-Specific Monoclonal Antibodies. J. Virol. 2016, 90, 6127-6139. [CrossRef] [PubMed]

169. Parsons, M.S.; Lee, W.S.; Kristensen, A.B.; Amarasena, T.; Khoury, G.; Wheatley, A.K.; Reynaldi, A.; Wines, B.D.; Hogarth, P.M.; Davenport, M.P.; et al. Fc-dependent functions are redundant to efficacy of anti-HIV antibody PGT121 in macaques. J. Clin. Investig. 2019, 129, 182-191. [CrossRef] [PubMed]

170. von Bredow, B.; Andrabi, R.; Grunst, M.; Grandea, A.G., 3rd; Le, K.; Song, G.; Berndsen, Z.T.; Porter, K.; Pallesen, J.; Ward, A.B.; et al. Differences in the Binding Affinity of an HIV-1 V2 Apex-Specific Antibody for the SIVsmm/mac Envelope Glycoprotein Uncouple Antibody-Dependent Cellular Cytotoxicity from Neutralization. MBio 2019, 10, e01255-19. [CrossRef] 
171. Malherbe, D.C.; Mendy, J.; Vang, L.; Barnette, P.T.; Reed, J.; Lakhashe, S.K.; Owuor, J.; Gach, J.S.; Legasse, A.W.; Axthelm, M.K.; et al. Combination Adenovirus and Protein Vaccines Prevent Infection or Reduce Viral Burden after Heterologous Clade C Simian-Human Immunodeficiency Virus Mucosal Challenge. J. Virol. 2018, 92. [CrossRef]

172. Hessell, A.J.; Malherbe, D.; Barnette, P.; Pandey, S.; Sutton, W.; Li, L.; Tuen, M.; Gach, J.S.; Forthal, D.N.; Duerr, R.; et al. Tight Control of SHIV Challenge in Macaques with Vaccine-Induced Neutralizing and Non-Neutralizing Anti-V2 Antibodies. In Proceedings of the Keystone Symposia, HIV Vaccines (X7), Whistler, BC, Canada, 24-28 March 2019.

173. Jones, A.T.; Shen, X.; Walter, K.L.; LaBranche, C.C.; Wyatt, L.S.; Tomaras, G.D.; Montefiori, D.C.; Moss, B.; Barouch, D.H.; Clements, J.D.; et al. HIV-1 vaccination by needle-free oral injection induces strong mucosal immunity and protects against SHIV challenge. Nat. Commun. 2019, 10, 798. [CrossRef]

174. Styles, T.M.; Gangadhara, S.; Reddy, P.B.J.; Hicks, S.; LaBranche, C.C.; Montefiori, D.C.; Derdeyn, C.A.; Kozlowski, P.A.; Velu, V.; Amara, R.R. HIV C.1086 Envelope Gp140 Protein Boosts Following DNA/MVA Vaccination Fail to Enhance Heterologous Anti-V1V2 Antibody Response and Protection Against Clade C SHIV Challenge. J. Virol. 2019, JVI.00934-19. [CrossRef]

175. Barouch, D.H.; Liu, J.; Li, H.; Maxfield, L.F.; Abbink, P.; Lynch, D.M.; Iampietro, M.J.; SanMiguel, A.; Seaman, M.S.; Ferrari, G.; et al. Vaccine protection against acquisition of neutralization-resistant SIV challenges in rhesus monkeys. Nature 2012, 482, 89-93. [CrossRef] [PubMed]

176. Gordon, S.N.; Doster, M.N.; Kines, R.C.; Keele, B.F.; Brocca-Cofano, E.; Guan, Y.; Pegu, P.; Liyanage, N.P.; Vaccari, M.; Cuburu, N.; et al. Antibody to the gp120 V1/V2 loops and CD4+ and CD8+ T cell responses in protection from SIVmac251 vaginal acquisition and persistent viremia. J. Immunol. 2014, 193, 6172-6183. [CrossRef] [PubMed]

177. Gordon, S.N.; Liyanage, N.P.; Doster, M.N.; Vaccari, M.; Vargas-Inchaustegui, D.A.; Pegu, P.; Schifanella, L.; Shen, X.; Tomaras, G.D.; Rao, M.; et al. Boosting of ALVAC-SIV Vaccine-Primed Macaques with the CD4-SIVgp120 Fusion Protein Elicits Antibodies to V2 Associated with a Decreased Risk of SIVmac251 Acquisition. J. Immunol. 2016, 197, 2726-2737. [CrossRef] [PubMed]

178. Pegu, P.; Vaccari, M.; Gordon, S.; Keele, B.F.; Doster, M.; Guan, Y.; Ferrari, G.; Pal, R.; Ferrari, M.G.; Whitney, S.; et al. Antibodies with high avidity to the gp120 envelope protein in protection from simian immunodeficiency virus SIV(mac251) acquisition in an immunization regimen that mimics the RV-144 Thai trial. J. Virol. 2013, 87, 1708-1719. [CrossRef] [PubMed]

179. Roederer, M.; Keele, B.F.; Schmidt, S.D.; Mason, R.D.; Welles, H.C.; Fischer, W.; Labranche, C.; Foulds, K.E.; Louder, M.K.; Yang, Z.Y.; et al. Immunological and virological mechanisms of vaccine-mediated protection against SIV and HIV. Nature 2014, 505, 502-508. [CrossRef] [PubMed]

180. Singh, S.; Ramirez-Salazar, E.G.; Doueiri, R.; Valentin, A.; Rosati, M.; Hu, X.; Keele, B.F.; Shen, X.; Tomaras, G.D.; Ferrari, G.; et al. Control of Heterologous Simian Immunodeficiency Virus SIVsmE660 Infection by DNA and Protein Coimmunization Regimens Combined with Different Toll-Like-Receptor-4-Based Adjuvants in Macaques. J. Virol. 2018, 92. [CrossRef] [PubMed]

181. Vaccari, M.; Fourati, S.; Gordon, S.N.; Brown, D.R.; Bissa, M.; Schifanella, L.; Silva de Castro, I.; Doster, M.N.; Galli, V.; Omsland, M.; et al. HIV vaccine candidate activation of hypoxia and the inflammasome in CD14(+) monocytes is associated with a decreased risk of SIVmac251 acquisition. Nat. Med. 2018, 24, 847-856. [CrossRef]

182. Kwa, S.; Sadagopal, S.; Shen, X.; Hong, J.J.; Gangadhara, S.; Basu, R.; Victor, B.; Iyer, S.S.; LaBranche, C.C.; Montefiori, D.C.; et al. CD40L-adjuvanted DNA/modified vaccinia virus Ankara simian immunodeficiency virus (SIV) vaccine enhances protection against neutralization-resistant mucosal SIV infection. J. Virol. 2015, 89, 4690-4695. [CrossRef]

183. Bohl, C.; Bowder, D.; Thompson, J.; Abrahamyan, L.; Gonzalez-Ramirez, S.; Mao, Y.; Sodroski, J.; Wood, C.; Xiang, S.H. A twin-cysteine motif in the V2 region of gp120 is associated with SIV envelope trimer stabilization. PLoS ONE 2013, 8, e69406. [CrossRef]

184. Hunt, P.W.; Sinclair, E.; Rodriguez, B.; Shive, C.; Clagett, B.; Funderburg, N.; Robinson, J.; Huang, Y.; Epling, L.; Martin, J.N.; et al. Gut epithelial barrier dysfunction and innate immune activation predict mortality in treated HIV infection. J. Infect. Dis. 2014, 210, 1228-1238. [CrossRef] 
185. Mehandru, S.; Poles, M.A.; Tenner-Racz, K.; Horowitz, A.; Hurley, A.; Hogan, C.; Boden, D.; Racz, P.; Markowitz, M. Primary HIV-1 infection is associated with preferential depletion of CD4+ T lymphocytes from effector sites in the gastrointestinal tract. J. Exp. Med. 2004, 200, 761-770. [CrossRef] [PubMed]

186. Schneider, T.; Jahn, H.U.; Schmidt, W.; Riecken, E.O.; Zeitz, M.; Ullrich, R. Loss of CD4 T lymphocytes in patients infected with human immunodeficiency virus type 1 is more pronounced in the duodenal mucosa than in the peripheral blood. Berlin Diarrhea/Wasting Syndrome Study Group. Gut 1995, 37, 524-529. [CrossRef] [PubMed]

187. Veazey, R.S.; DeMaria, M.; Chalifoux, L.V.; Shvetz, D.E.; Pauley, D.R.; Knight, H.L.; Rosenzweig, M.; Johnson, R.P.; Desrosiers, R.C.; Lackner, A.A. Gastrointestinal tract as a major site of CD4+ T cell depletion and viral replication in SIV infection. Science 1998, 280, 427-431. [CrossRef] [PubMed]

188. Berlin, C.; Berg, E.L.; Briskin, M.J.; Andrew, D.P.; Kilshaw, P.J.; Holzmann, B.; Weissman, I.L.; Hamann, A.; Butcher, E.C. Alpha 4 beta 7 integrin mediates lymphocyte binding to the mucosal vascular addressin MAdCAM-1. Cell 1993, 74, 185-195. [CrossRef]

189. Cicala, C.; Martinelli, E.; McNally, J.P.; Goode, D.J.; Gopaul, R.; Hiatt, J.; Jelicic, K.; Kottilil, S.; Macleod, K.; O'Shea, A.; et al. The integrin alpha4beta7 forms a complex with cell-surface CD4 and defines a T-cell subset that is highly susceptible to infection by HIV-1. Proc. Natl. Acad. Sci. USA 2009, 106, 20877-20882. [CrossRef] [PubMed]

190. Kader, M.; Wang, X.; Piatak, M.; Lifson, J.; Roederer, M.; Veazey, R.; Mattapallil, J.J. Alpha4(+)beta7(hi)CD4(+) memory T cells harbor most Th-17 cells and are preferentially infected during acute SIV infection. Mucosal Immunol. 2009, 2, 439-449. [CrossRef] [PubMed]

191. Arthos, J.; Cicala, C.; Martinelli, E.; Macleod, K.; Van Ryk, D.; Wei, D.; Xiao, Z.; Veenstra, T.D.; Conrad, T.P.; Lempicki, R.A.; et al. HIV-1 envelope protein binds to and signals through integrin alpha4beta7, the gut mucosal homing receptor for peripheral T cells. Nat. Immunol. 2008, 9, 301-309. [CrossRef]

192. Peachman, K.K.; Karasavvas, N.; Chenine, A.L.; McLinden, R.; Rerks-Ngarm, S.; Jaranit, K.; Nitayaphan, S.; Pitisuttithum, P.; Tovanabutra, S.; Zolla-Pazner, S.; et al. Identification of New Regions in HIV-1 gp120 Variable 2 and 3 Loops that Bind to alpha4beta7 Integrin Receptor. PLoS ONE 2015, 10, e0143895. [CrossRef]

193. Tassaneetrithep, B.; Tivon, D.; Swetnam, J.; Karasavvas, N.; Michael, N.L.; Kim, J.H.; Marovich, M.; Cardozo, T. Cryptic determinant of alpha4beta7 binding in the V2 loop of HIV-1 gp120. PLoS ONE 2014, 9, e108446. [CrossRef]

194. Plotnik, D.; Guo, W.; Cleveland, B.; von Haller, P.; Eng, J.K.; Guttman, M.; Lee, K.K.; Arthos, J.; Hu, S.L. Extracellular Matrix Proteins Mediate HIV-1 gp120 Interactions with alpha4beta7. J. Virol. 2017, 91. [CrossRef]

195. Perez, L.G.; Chen, H.; Liao, H.X.; Montefiori, D.C. Envelope glycoprotein binding to the integrin alpha4beta7 is not a general property of most HIV-1 strains. J. Virol. 2014, 88, 10767-10777. [CrossRef] [PubMed]

196. Chand, S.; Messina, E.L.; AlSalmi, W.; Ananthaswamy, N.; Gao, G.; Uritskiy, G.; Padilla-Sanchez, V.; Mahalingam, M.; Peachman, K.K.; Robb, M.L.; et al. Glycosylation and oligomeric state of envelope protein might influence HIV-1 virion capture by alpha4beta7 integrin. Virology 2017, 508, 199-212. [CrossRef] [PubMed]

197. Nawaz, F.; Cicala, C.; Van Ryk, D.; Block, K.E.; Jelicic, K.; McNally, J.P.; Ogundare, O.; Pascuccio, M.; Patel, N.; Wei, D.; et al. The genotype of early-transmitting HIV gp120s promotes alpha (4) beta(7)-reactivity, revealing alpha (4) beta(7) +/CD4+ T cells as key targets in mucosal transmission. PLoS Pathog. 2011, 7, e1001301. [CrossRef] [PubMed]

198. Sivro, A.; Schuetz, A.; Sheward, D.; Joag, V.; Yegorov, S.; Liebenberg, L.J.; Yende-Zuma, N.; Stalker, A.; Mwatelah, R.S.; Selhorst, P.; et al. Integrin alpha4beta7 expression on peripheral blood CD4(+) T cells predicts HIV acquisition and disease progression outcomes. Sci. Transl. Med. 2018, 10. [CrossRef] [PubMed]

199. Martinelli, E.; Veglia, F.; Goode, D.; Guerra-Perez, N.; Aravantinou, M.; Arthos, J.; Piatak, M., Jr.; Lifson, J.D.; Blanchard, J.; Gettie, A.; et al. The frequency of alpha(4)beta(7)(high) memory CD4(+) T cells correlates with susceptibility to rectal simian immunodeficiency virus infection. J. Acquir. Immune Defic. Syndr. 2013, 64, 325-331. [CrossRef]

200. Ding, J.; Tasker, C.; Lespinasse, P.; Dai, J.; Fitzgerald-Bocarsly, P.; Lu, W.; Heller, D.; Chang, T.L. Integrin alpha4beta7 Expression Increases HIV Susceptibility in Activated Cervical CD4+ T Cells by an HIV Attachment-Independent Mechanism. J. Acquir. Immune Defic. Syndr. 2015, 69, 509-518. [CrossRef] [PubMed] 
201. Nakamura, G.R.; Fonseca, D.P.; O'Rourke, S.M.; Vollrath, A.L.; Berman, P.W. Monoclonal antibodies to the V2 domain of MN-rgp120: Fine mapping of epitopes and inhibition of alpha4beta7 binding. PLOS ONE 2012, 7, e39045. [CrossRef]

202. Lertjuthaporn, S.; Cicala, C.; Van Ryk, D.; Liu, M.; Yolitz, J.; Wei, D.; Nawaz, F.; Doyle, A.; Horowitch, B.; Park, C.; et al. Select gp120 V2 domain specific antibodies derived from HIV and SIV infection and vaccination inhibit gp120 binding to alpha4beta7. PLoS Pathog. 2018, 14, e1007278. [CrossRef]

203. Arthos, J.; Cicala, C.; Nawaz, F.; Byrareddy, S.N.; Villinger, F.; Santangelo, P.J.; Ansari, A.A.; Fauci, A.S. The Role of Integrin alpha4beta7 in HIV Pathogenesis and Treatment. Curr. HIV/AIDS Rep. 2018, 15, 127-135. [CrossRef]

204. Uzzan, M.; Tokuyama, M.; Rosenstein, A.K.; Tomescu, C.; SahBandar, I.N.; Ko, H.M.; Leyre, L.; Chokola, A.; Kaplan-Lewis, E.; Rodriguez, G.; et al. Anti-alpha4beta7 therapy targets lymphoid aggregates in the gastrointestinal tract of HIV-1-infected individuals. Sci. Transl. Med. 2018, 10. [CrossRef]

205. Ansari, A.A.; Reimann, K.A.; Mayne, A.E.; Takahashi, Y.; Stephenson, S.T.; Wang, R.J.; Wang, X.Y.; Li, J.C.; Price, A.A.; Little, D.M.; et al. Blocking of alpha 4 beta 7 Gut-Homing Integrin during Acute Infection Leads to Decreased Plasma and Gastrointestinal Tissue Viral Loads in Simian Immunodeficiency Virus-Infected Rhesus Macaques. J. Immunol. 2011, 186, 1044-1059. [CrossRef] [PubMed]

206. Byrareddy, S.N.; Kallam, B.; Arthos, J.; Cicala, C.; Nawaz, F.; Hiatt, J.; Kersh, E.N.; McNicholl, J.M.; Hanson, D.; Reimann, K.A.; et al. Targeting alpha(4)beta(7) integrin reduces mucosal transmission of simian immunodeficiency virus and protects gut-associated lymphoid tissue from infection. Nat. Med. 2014, 20, 1397-1400. [CrossRef]

207. Byrareddy, S.N.; Arthos, J.; Cicala, C.; Villinger, F.; Ortiz, K.T.; Little, D.; Sidell, N.; Kane, M.A.; Yu, J.; Jones, J.W.; et al. Sustained virologic control in SIV+ macaques after antiretroviral and alpha4beta7 antibody therapy. Science 2016, 354, 197-202. [CrossRef] [PubMed]

208. Ling, L.; Wu, T.; To, K.K.W.; Cheung, K.W.; Lui, K.O.; Niu, M.; Lam, K.S.; Wang, C.C.; Li, J.; Wang, H.; et al. Vedolizumab-mediated integrin alpha4beta7 blockade does not control HIV-1SF162 rebound after cART interruption in humanized mice. AIDS 2019, 33, F1-F12. [CrossRef] [PubMed]

209. Iwamoto, N.; Mason, R.; Song, K.; Gorman, J.; Welles, H.; Arthos, J.; Cicala, C.; Foulds, K.; Kwong, P.; Lifson, J.; et al. SIV Escapes from Non-neutralizing Antibodies Blocking $\alpha 4 \beta 7$ Integrin Binding. In Proceedings of the Keystone Symposia, HIV Vaccines, Whistler, BC, Canada, 24-28 March 2019.

210. McGuinty, M.; Angel, J.; Kumar, A.; Sy, R.; Murthy, S.; Kilby, D.; Tremblay, N.; Lavoie, E.; Schinkel, S.B.; Byrareddy, S.N.; et al. Seeking suppression in havarti: Viremia and T cells after vedolizumab and analytical treatment interruption in HIV/ART. In Proceedings of the Conference on Retroviruses and Opportunistic Infections (CROI), Seattle, WA, USA, 4-7 March 2019.

211. Girard, A.; Jelicic, K.; Van Ryk, D.; Rochereau, N.; Cicala, C.; Arthos, J.; Noailly, B.; Genin, C.; Verrier, B.; Laurant, S.; et al. Neutralizing and Targeting Properties of a New Set of alpha4beta7-Specific Antibodies Are Influenced by Their Isotype. J. Acquir. Immune Defic. Syndr. 2017, 75, 118-127. [CrossRef] [PubMed]

212. Hait, S.H.; Soares, E.A.; Sprinz, E.; Arthos, J.; Machado, E.S.; Soares, M.A. Worldwide Genetic Features of HIV-1 Env alpha4beta7 Binding Motif: The Local Dissemination Impact of the LDI Tripeptide. J. Acquir. Immune Defic. Syndr. 2015, 70, 463-471. [CrossRef] [PubMed]

213. Courtney, C.R.; Mayr, L.; Nanfack, A.J.; Banin, A.N.; Tuen, M.; Pan, R.; Jiang, X.; Kong, X.P.; Kirkpatrick, A.R.; Bruno, D; et al. Contrasting antibody responses to intrasubtype superinfection with CRF02_AG. PLoS ONE 2017, 12, e0173705. [CrossRef] [PubMed]

214. Redd, A.D.; Quinn, T.C.; Tobian, A.A. Frequency and implications of HIV superinfection. Lancet Infect. Dis. 2013, 13, 622-628. [CrossRef]

215. Moore, P.L.; Gray, E.S.; Sheward, D.; Madiga, M.; Ranchobe, N.; Lai, Z.; Honnen, W.J.; Nonyane, M.; Tumba, N.; Hermanus, T.; et al. Potent and broad neutralization of HIV-1 subtype C by plasma antibodies targeting a quaternary epitope including residues in the V2 loop. J. Virol. 2011, 85, 3128-3141. [CrossRef]

216. Bhiman, J.N.; Anthony, C.; Doria-Rose, N.A.; Karimanzira, O.; Schramm, C.A.; Khoza, T.; Kitchin, D.; Botha, G.; Gorman, J.; Garrett, N.J.; et al. Viral variants that initiate and drive maturation of V1V2-directed HIV-1 broadly neutralizing antibodies. Nat. Med. 2015, 21, 1332-1336. [CrossRef]

217. Voss, J.E.; Andrabi, R.; McCoy, L.E.; de Val, N.; Fuller, R.P.; Messmer, T.; Su, C.Y.; Sok, D.; Khan, S.N.; Garces, F.; et al. Elicitation of Neutralizing Antibodies Targeting the V2 Apex of the HIV Envelope Trimer in a Wild-Type Animal Model. Cell Rep. 2017, 21, 222-235. [CrossRef] [PubMed] 
218. Ackerman, M.E.; Barouch, D.H.; Alter, G. Systems serology for evaluation of HIV vaccine trials. Immunol. Rev. 2017, 275, 262-270. [CrossRef] [PubMed]

219. Chung, A.W.; Kumar, M.P.; Arnold, K.B.; Yu, W.H.; Schoen, M.K.; Dunphy, L.J.; Suscovich, T.J.; Frahm, N.; Linde, C.; Mahan, A.E.; et al. Dissecting Polyclonal Vaccine-Induced Humoral Immunity against HIV Using Systems Serology. Cell 2015, 163, 988-998. [CrossRef] [PubMed]

220. Yates, N.L.; de Camp, A.C.; Korber, B.T.; Liao, H.X.; Irene, C.; Pinter, A.; Peacock, J.; Harris, L.J.; Sawant, S.; Hraber, P.; et al. HIV-1 Envelope Glycoproteins from Diverse Clades Differentiate Antibody Responses and Durability among Vaccinees. J. Virol. 2018, 92. [CrossRef] [PubMed]

221. Powell, R.L.R.; Totrov, M.; Itri, V.; Liu, X.; Fox, A.; Zolla-Pazner, S. Plasticity and Epitope Exposure of the HIV-1 Envelope Trimer. J. Virol. 2017, 91. [CrossRef] [PubMed]

222. Curlin, M.E.; Zioni, R.; Hawes, S.E.; Liu, Y.; Deng, W.; Gottlieb, G.S.; Zhu, T.; Mullins, J.I. HIV-1 envelope subregion length variation during disease progression. PLoS Pathog. 2010, 6, e1001228. [CrossRef] [PubMed]

223. Van Gils, M.J.; Bunnik, E.M.; Boeser-Nunnink, B.D.; Burger, J.A.; Terlouw-Klein, M.; Verwer, N.; Schuitemaker, H. Longer V1V2 region with increased number of potential N-linked glycosylation sites in the HIV-1 envelope glycoprotein protects against HIV-specific neutralizing antibodies. J. Virol. 2011, 85, 6986-6995. [CrossRef]

224. McGuire, E.P.; Fong, Y.; Toote, C.; Cunningham, C.K.; McFarland, E.J.; Borkowsky, W.; Barnett, S.; Itell, H.L.; Kumar, A.; Gray, G.; et al. HIV-Exposed Infants Vaccinated with an MF59/Recombinant gp120 Vaccine Have Higher-Magnitude Anti-V1V2 IgG Responses than Adults Immunized with the Same Vaccine. J. Virol. 2017, 92. [CrossRef]

225. Permar, S.R.; Fong, Y.Y.; Vandergrift, N.; Fouda, G.G.; Gilbert, P.; Parks, R.; Jaeger, F.H.; Pollara, J.; Martelli, A.; Liebl, B.E.; et al. Maternal HIV-1 envelope-specific antibody responses and reduced risk of perinatal transmission. J. Clin. Investig. 2015, 125, 270-2706. [CrossRef]

226. Trinh, H.V.; Gohain, N.; Pham, P.T.; Hamlin, C.; Song, H.; Sanders-Buell, E.; Bose, M.; Eller, L.A.; Jain, S.; Uritskiy, G.; et al. Humoral Response to the HIV-1 Envelope V2 Region in a Thai Early Acute Infection Cohort. Cells 2019, 8. [CrossRef]

227. Munro, J.B.; Gorman, J.; Ma, X.; Zhou, Z.; Arthos, J.; Burton, D.R.; Koff, W.C.; Courter, J.R.; Smith, A.B., 3rd; Kwong, P.D.; et al. Conformational dynamics of single HIV-1 envelope trimers on the surface of native virions. Science 2014, 346, 759-763. [CrossRef]

228. Lu, M.; Ma, X.; Castillo-Menendez, L.R.; Gorman, J.; Alsahafi, N.; Ermel, U.; Terry, D.S.; Chambers, M.; Peng, D.; Zhang, B.; et al. Associating HIV-1 envelope glycoprotein structures with states on the virus observed by smFRET. Nature 2019, 568, 415-419. [CrossRef] [PubMed]

229. Prevost, J.; Richard, J.; Ding, S.; Pacheco, B.; Charlebois, R.; Hahn, B.H.; Kaufmann, D.E.; Finzi, A. Envelope glycoproteins sampling states $2 / 3$ are susceptible to ADCC by sera from HIV-1-infected individuals. Virology 2018, 515, 38-45. [CrossRef] [PubMed]

230. Gray, E.S.; Madiga, M.C.; Hermanus, T.; Moore, P.L.; Wibmer, C.K.; Tumba, N.L.; Werner, L.; Mlisana, K.; Sibeko, S.; Williamson, C.; et al. The neutralization breadth of HIV-1 develops incrementally over four years and is associated with CD4+ T cell decline and high viral load during acute infection. J. Virol. 2011, 85, 4828-4840. [CrossRef] [PubMed]

231. Martin, M.P.; Carrington, M. Immunogenetics of HIV disease. Immunol. Rev. 2013, 254, 245-264. [CrossRef] [PubMed]

232. Rolland, M.; Gilbert, P. Evaluating immune correlates in HIV type 1 vaccine efficacy trials: What RV144 may provide. AIDS Res. Hum. Retrovir. 2012, 28, 400-404. [CrossRef] [PubMed]

(C) 2019 by the authors. Licensee MDPI, Basel, Switzerland. This article is an open access article distributed under the terms and conditions of the Creative Commons Attribution (CC BY) license (http://creativecommons.org/licenses/by/4.0/). 